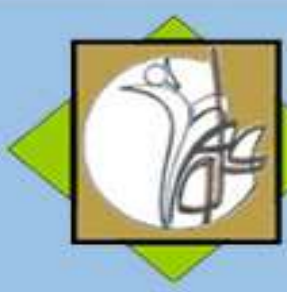

Research Article

\title{
Determining the Mediator's Role of Competitive Advantage and Organizational Reputation in the Causal Relationship Between the Social Responsibility and Team Performance of the Persepolis Club
}

\author{
Samaneh Saeidpour ${ }^{1}$, Najaf Aghaei $^{2}$ \\ 1. Samaneh Saeidpour, (MA) Kharazmi University,Tehran,Iran. \\ 2. Najaf Aghaei, (Ph. D) Kharazmi University,Tehran,Iran.
}

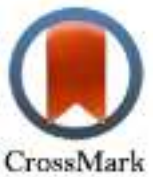

\section{ARTICLE INFO}

Received May 2019

Accepted March 2020

\section{KEYWORDS:}

Carroll's model, Sports

Performance, Competitive

Advantage, Reputation

CITE:

Saeidpour, Aghaei. Determining the Mediator's Role of

Competitive Advantage and

Organizational Reputation in the

Causal Relationship Between the

Social Responsibility and Team

Performance of the Persepolis

Club, Research in Sport

Management \& Motor Behavior,

2021: 11(21): 160-183

d.i $10.52547 / J R S M .11 .21 .160$

\section{ABSTRACT}

The purpose of this study was to determine the role of mediator of competitive advantage and organizational reputation in the causal relationship between social responsibility and Team performance of Persepolis Club. The research method is descriptive-survey in terms of purpose and applied with a structural equation approach. The statistical population included all Persepolis fans and the sample size according to Morgan table was 384 people (randomly).The Ressler's Club Reputation Questionnaire (2010), Hosseini's Competitive Advantage (2011), Galbrith Social Responsibility (2010), Glenn Team Performance (2003), Hosseini (2016), Cooper and Satter (2011) were used. Descriptive and inferential statistics with SEM approach were used to analyze the data; The results were analyzed using SPSS22 and Smart PLS3 software. It was found that social responsibility has a positive and significant effect on team performance, competitive advantage and organizational reputation. The direct and significant effect of reputation on team performance and the mediating role of reputation was minor confirmed. However, the effect of competitive advantage on team performance and the mediating role of competitive advantage was not confirmed. It is suggested that Persepolis, by performing social responsibilities in economic, ethical, legal and humanitarian dimensions, promote the reputation, competitive advantage and team performance of the club. 


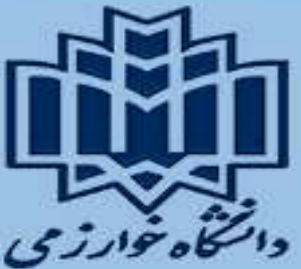

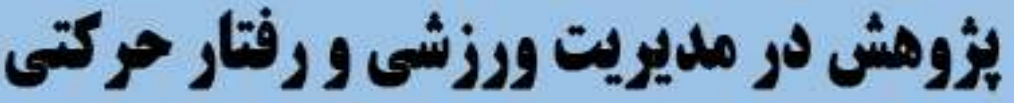

مقاله بُؤوهى

\section{تعيين نقش ميانجى مزيت رقابتى و شهرت سازماذى در رابطهُ علّى مسئوليت اجتماعى و عملكرد تيمى باشكاه ير سيوليس}

\author{
سمانه سعيد يور'، نجف آقايى
}

ا. كارشناسى ارشد مديريت ورزشى، دانشكده تربيت بدنى وعلوم ورزشى، دانشگاه خوارزمى، تهران، ايران.

r. دانشيار كروه مديريت ورزشى و رفتار حركتى، دانشكده تربيت بدنى وعلوم ورزشى، دانشكاه خوارزمى، تهران، ايران.

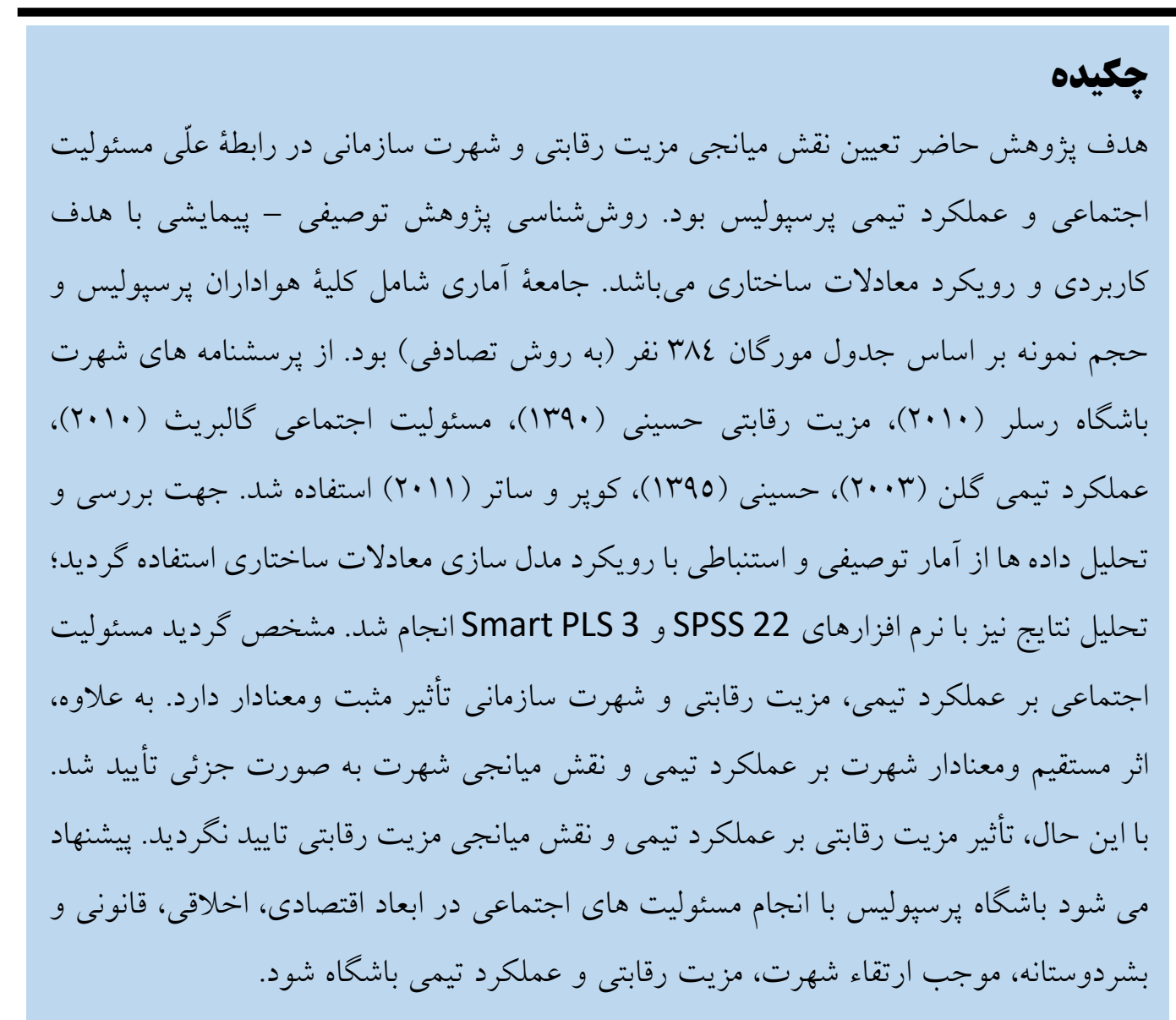

اطلاعات مقاله:

دريافت مقاله ارديبهشت

بذيرش مقاله اسفند يه"|

ثقويسنله مسئول:

aghaei.hamid@gmail.com

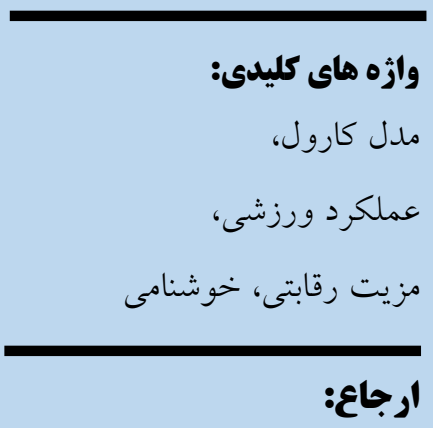

سعيد يور، آقايى. تعيين نقش ميانجى مزيت رقابتى و شهرت سازمانى در

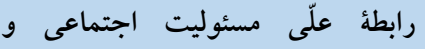
عملكرد تيمى باشكاه برسيوليس. ئزوهش در مديريت ورزشى و رفتار حركتى، • •ع ا: ||(Y) 


\section{Research in Sport Management and Motor Behavior, Volume 11 - Issue 21 / May 2021}

مقدمه

در دنياى كنونى به علّت استرسهاى موجود، مردم زمان بيشترى راصرف اوقات فراغت خود مى كنند و تماشاى مسابقات ورزشى يكى از فعاليتهاى محبوب در اوقات فراغت مىباشد (1). در بين رشتههاى ورزشى كه در سراسر دنيا داراى مسابقات منظم است، بىترديد ورزش فوتبال، از برطرفدارترين و برمشاركت ترين فعاليت و رشتهُ ورزشى به شمار مى آيد، تا آنجا كه بسيارى از كشورهاى ينج قاره جهان آن را در رديف ورزش ملّى خود محسوبك بكردهاند. در كشور ما نيز فوتبال رايجترين و برطرفدارترين ورزش است و در مقايسه با تمامى رشتهها بيشترين تعداد ورزشكاران و تماشاكران را به خود

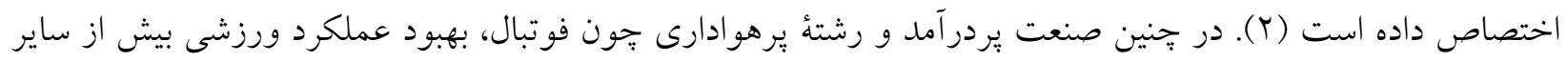
صنايع و رشتهها اهميت مىيابد و براساس اهداف و شاخصهاى مختلفى بررسى و ارزيابى مىشود؛ به طورى كه باشكاههاى ورزشى را مى توان براساس عملكرد ورزشى و غير ورزشى بررسى كرد. عملكرد ورزشى شامل نتايج و رتبههاى

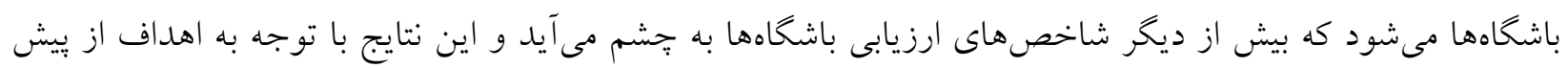
تعيين شده باشگاهها و براساس داثتهها و امكانات موجود تحت بررسى قرار مى گيرد. عملكرد غيرورزشى در باشكاهها نيز بيشتر شامل شاخص هاى مالى مىشوند كه از اهميت زيادى در ارزيابى باشخاهها برخوردار است (ب). البته به كفتهُ بيل و همكاران (Y...r) عملكرد تيمها علاوه بر نتايج و امتيازات تيم، با رفتار تيمها هم مىتواند سنجيده شود (ع). عوامل

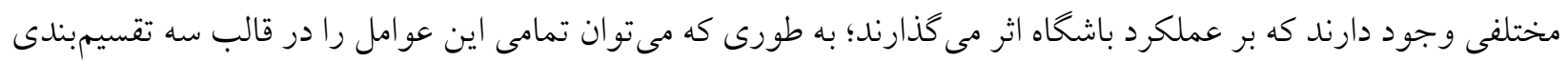
كلى شامل، مديريت باشگاه، كادر فنى و بازيكنان قرار داد (0و 7). بنابراين، مى توان كفت هر فر فعاليتى كه توسط سه كروه

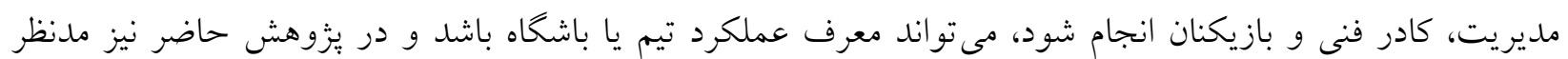

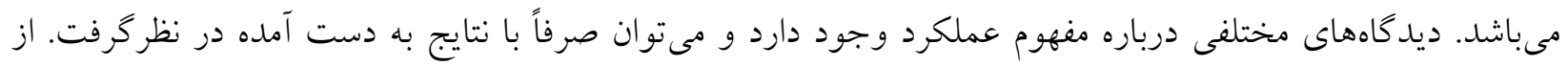
لحاظ فردى نيز، عملكرد به سابقُ موفقيتهاى يك شخص اشاره دارد (V). بنابراين، عوامل متعددى وجود دارند كه بر عملكرد سازمانها اثر كذارند و بايد بدانها توجه شود. باشخاههاى ورزشى هم كه نوعى سازمان محسوب مى شوند از اين امر جدا نيستند. بر اساس بثزوهشهاى مختلف مسئوليت اجتماعى شركت 'يكى از عو امل مرتبط با عملكرد تيمى مى باشد

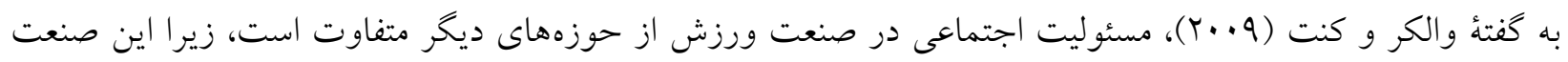
ويزگى هاى خاصى دارد كه آن را از ديكر سازمانها در حوزهُ تجارت متمايز مى كند (9). بدون شك مدل مسئوليت اجتماعى كارول (9V9)، به عنوان يراستفادهترين مدل نقل قول شده است. كه جهار بعد اقتصادى، قانونى، اخلاقى و بشردوستانه (نوعدوستى) را شامل مى شود. مسئوليت اقتصادى به عنوان پايه و اساس كه شالوده همهُ ابعاد در هرم مسئوليت اجتماعى شركت است توصيف مىشود. به عقيده كارول مهمترين بعد است زيرا به عنوان يكى منبع مزيت رقابتى پايدار

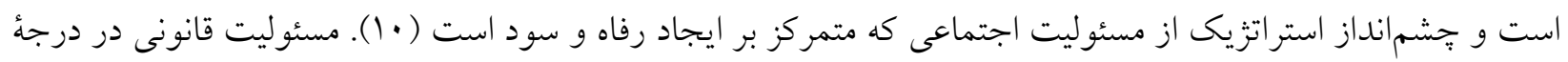

${ }^{1}$ Corporate Social Responsibility (CSR)

https://jrsm.khu.ac.ir/ 
كمترى از بعد قبلى قرار دارد و نشان دهنده اين اصل است كه هر كسب وكار مستلزم بيروى از قوانين و مقررات تعيين شده براى صلاح همخان است و بيروى از قوانينى تجون نظارت و كنترل رويهها، قانون ايمنى و سلامت كار، استانداردهاى اجبارى و حفظ محيط زيست در زمره اين قوانين جا مى گيرند (11). مسئوليتهاى اخلاقى به عنوان انتظارات اجتماعى افراد جامعه از كسب و كارها بيش از نيازمندى قانونى توصيف مى شود. بهطور مثال اصولى همجيون صداقت، انصاف و احترام. مسئوليت بشردوستانه نيز نقشهايى است كه خالصانه به صورت داوطلبانه انجام مى گردد و تصميم براى تقبل كردن آن، به دليل تمايل شركتها براى مشاركت در نقشهاى اجتماعى است كـه نيازمند قانون نمى باشد؛ تعبير ديخر

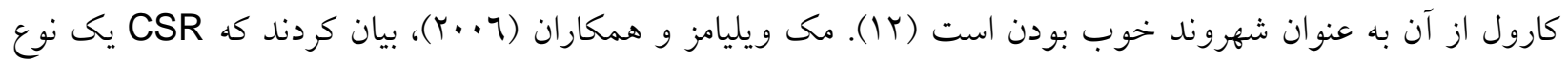

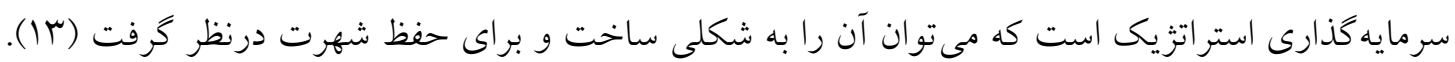
شهرت سازمان را مىتوان نتيجه ادراكات مشتريان از تجربيات، اطلاعات مستقيم و غيرمستقيمى دانست كه حاصل فعاليتهاى قبلى سازمان است (ع (). مايلز و كوين (.......)، معتقدند شهرت يك شاخص اعتبار، اعتماد، قابليت اطمينان و مسئوليت سازمان است. سازمانهايى كه محصولات با كيفيت بالا را توليد مى كنند، از تبليغات مناسب استفاده مىكنند، به مسئوليت اجتماعى و زيست محيطى علاقمندند و تعهدات خود را نسبت به سهامداران انجام مى دهند، مى توانند شهرت خوبى ايجاد كنند. جرا كه يكى از دارايى هاى ناملموس است كه در آن بازاريابى و عملكرد مالى مورد توجه قرار مى گيرد (10 او 17). در صنعت ورزش نيز كه از بديدههاى بسيار مؤثر بر جامعهُ مدرن است و در سطح بينالمللى، يازدهمين رتبه

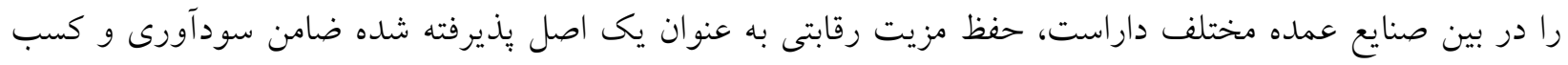
ثروت سازمانها و شركتهاى ورزشى است؛ كه در اين فضاى به شدت رقابتى، سازمانها مسئوليت اجتماعى را نوعى استراتزى تجارى مىبينند كه موجب مىشود بر شهرت و اعتبارشان افزوده شود و سهمشان در بازار فزونى گيرد (IV).

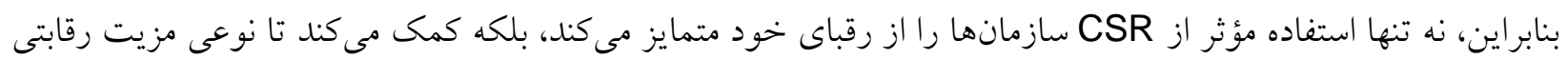

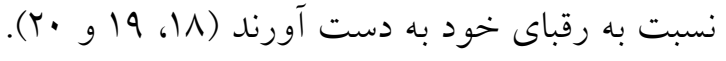

مزيت رقابتى فرآيند دنبالهدارى است كه به عملكرد بهتر سازمان منجر مىشود. درصورتى كه سازمان بتواند به واسطة

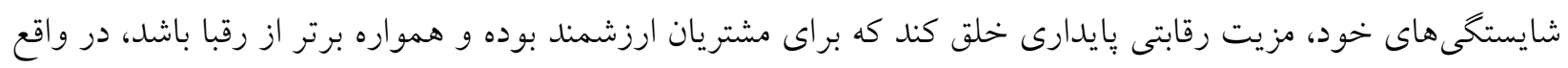

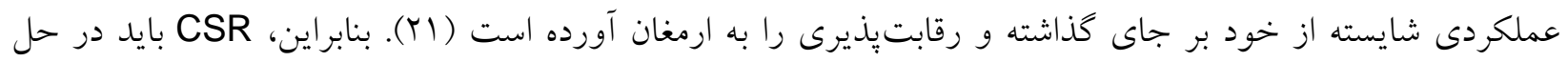
معضلات اجتماعى جامعه نمود يابد و به عنوان ابزارى قدرتمند در جهت توانمند كردن باشكاهها و هيأتهاى ورزشى در سطح اجتماع مدنظر قراركيرد، زيرا مطابق با نتايج تحقيقات مختلف يك مؤلفهُ كليدى از جعبه ابزار بازاريابى است كه

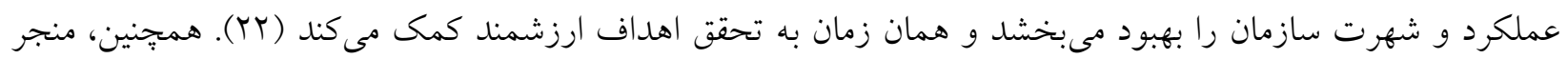
به افزايش عملكرد مالى، رضايت بازيكنان و هو اداران (Tr) و توان رقابتى خواهد شد (ع (Y). به طوركلى مى توان كفت،

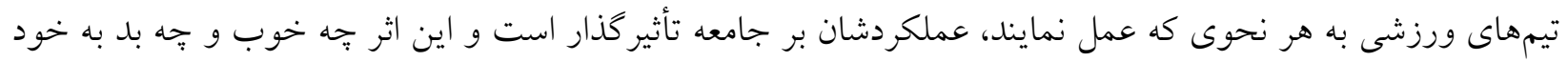
تيمها منعكس مىشود. به طورى كه انجام اقداماتى همجيون مسئوليتهاى اجتماعى مى تواند بر عملكرد تيمى تأثير كذار 
باشد (Y0). در همين راستا، رسولزاده و همكاران (T/ (Y) در يزووهشى بين ابعاد مسئوليت اجتماعى و عملكرد ارتباط معنادارى به دست آوردند (YT). تحقيقات ديخرى اشاره كردند كه فعاليتهاى CSR، عملكرد شركت را افزايش مىدهد

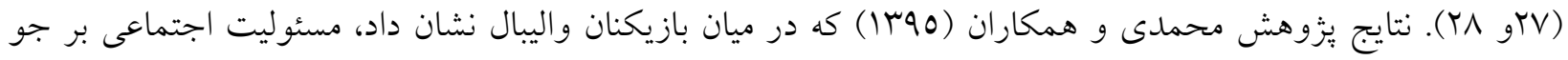
اخلاقى و عملكرد ادراى شده تأثير مستقيم و معنادار دارد؛ اما اثر مستقيم جو اخلاقى و اثر غيرمستقيم مسئوليت اجتماعى مئى بر عملكرد ادراك شده معنى دار نبود. بنابر اين، لازمهُ موفقيت يك تيم، عملكرد مناسب آن است. كه در يُوهش محمدى، مسئوليت اجتماعى به عنوان يكى از عوامل اثر گذار بر عملكرد تيمى شناخته شد (Y0). يكى از مسائل مهم در بحث مسئوليت اجتماعى شركت، اين است كه آيا منجر به بهبود رقابت مىشود؟ (Y9). نيورو (10 (Y)، اشاره كرد كه فعاليتهاى

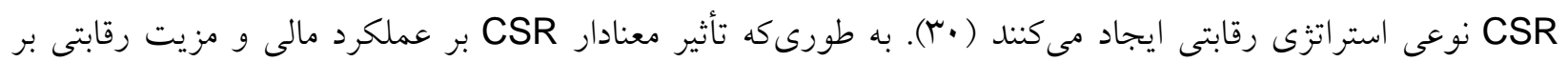

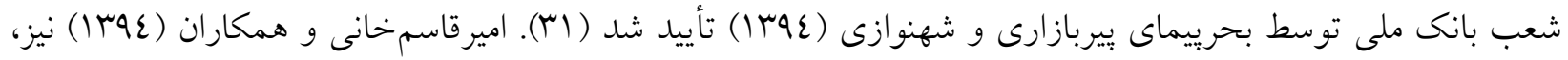

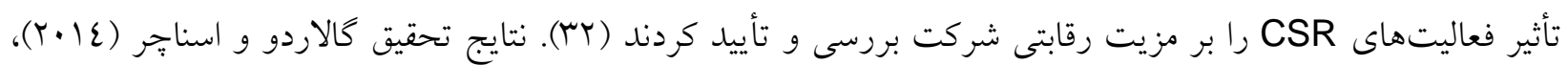
نشان مى دهد كه CSR نقش مهمى در عملكرد و موفقيت رقابتى سازمانها دارد (بT). مسئوليت اجتماعى شركت، به

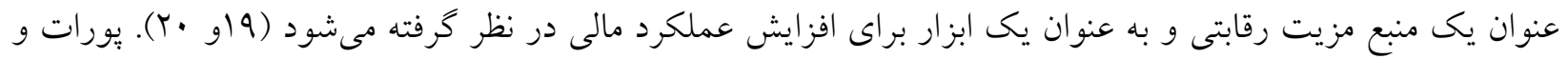

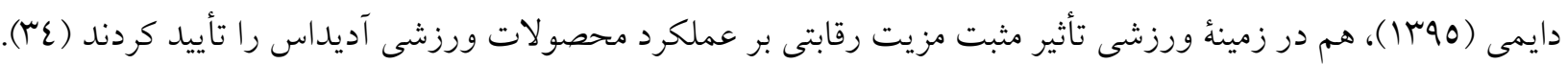

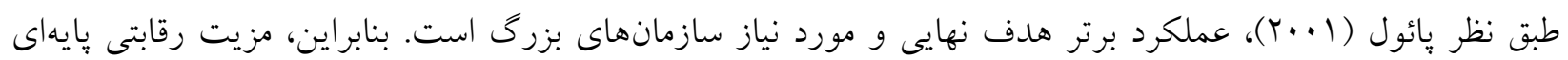
براى دستيابى به اين عملكرد است (ro). يكى ديخر از روشهايى كه مزاياى اندازه گيرىهاى مسئوليت اجتماعى جامعه را

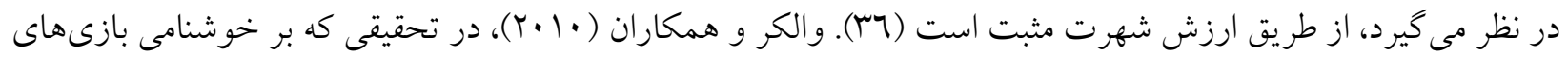

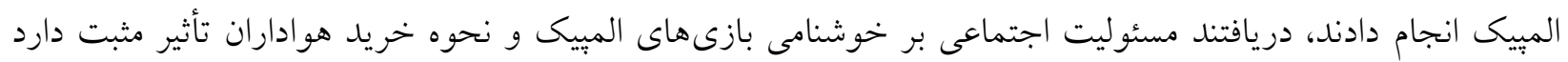

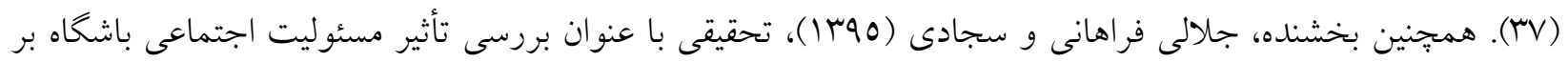
خوشنامى (شهرت) تيمهاى منتخب ليخ برتر فوتبال ايران انجام دادند و گزارش كردند كه تمام ابعاد مسئوليت اجتماعى (اقتصادى، قانونى، اخلاقى و بشر دوستانه) بر خوشنامى تأثير مثبت دارد؛ به عبارت ديخر، با افزايش هريكى از شاخصهاى

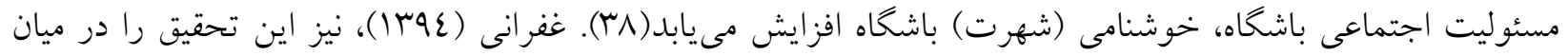
باشكاههاى بدنسازى انجام داد و ارتباط بين CSR و خوشنامى (شهرت) را مثبت كزارش كرد (Yq). در تحقيق سجادى و جاوران (T/ (Y)، نيز كه باعنوان تأثير مسئوليت اجتماعى بر شهرت باشكاه بر روى طرفداران تيم فوتبال ليخ برتر ايران انجام كرفت، مشخص شد كه مسئوليت اجتماعى اثر قابل توجهى بر شهرت باشخاه دارد ( •ع). البته يزّوهش بولانسكى و و

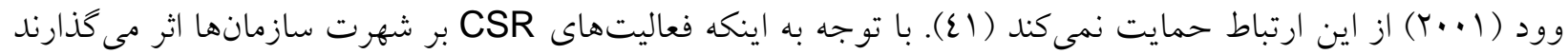
مهم است تحقيق كنيم در مورد اينكه آيا شهرت سازمانى بر عملكرد تيمها نيز تأثير دارد؟ جرا كه بررسى تأثير ميانجى آنى شهرت سازمانى مى تواند به درك ما از مكانيزمى كه از طريق آن مسئوليت اجتماعى بر عملكرد سازمان تأثير مى كذارد، كمك كند ( اع). تعدادى از مطالعات تجربى وجود دارد كه از ديد كاهى كه شهرت سازمانها بر عملكرد آن تأثير مى كذارد 


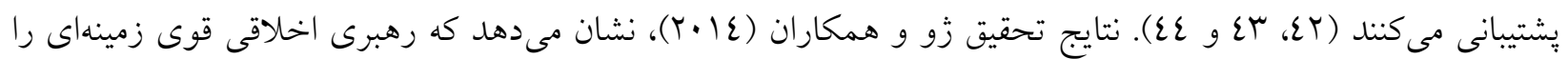
فراهم مى كند كه در آن مسئوليتهاى اجتماعى شركت يك شهرت مثبت در بين ذينفعان ايجاد كند، كه در نهايت باعث

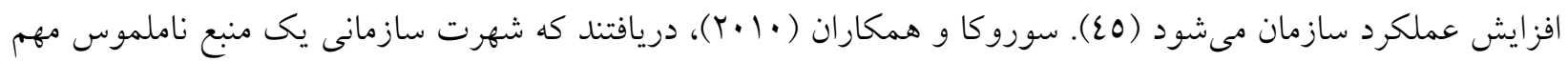
است كه در نتيجه مسئوليت عملكرد شركت است و از آنجايى كه نوعى مزيت رقابتى ايجاد مىكند، بر عملكرد مالى نيز

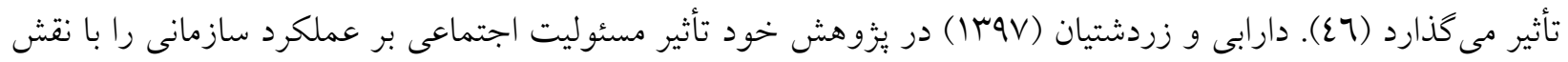
ميانجى خوشنامى را در ميان كاركنان ادارات ورزش و جوانان غرب ايران سنجيدند. نتايج از اثركذارى مثبت و مستقيم مسئوليت اجتماعى بر عملكرد سازمانى، مسئوليت اجتماعى بر خوشنامى، خوشنامى بر عملكرد سازمانى و تأثير غيرمستقيم و معنادار مسئوليت اجتماعى بر عملكرد سازمانى با نقش ميانجى خوشنامى در بزوهش حمايت كردند (EV). مرور يزوهشها و ادبيات موجود نشان داد مبحث گسترده و مهمى همجيون CSR مى تواند توسط يزوهشخران بسيارى در علوم مختلف مورد بررسى قرار گيرد و تأثيرش بر متغيرهاى مختلفى همجيون عملكرد، نتايج متفاوتى را ارائه دهد. البته در حيطه ورزش و رشته يرطرفدار فوتبال يُزوهشى كه نقش مسئوليت اجتماعى بر عملكرد تيمى را بسنجد، يافت نشد. به

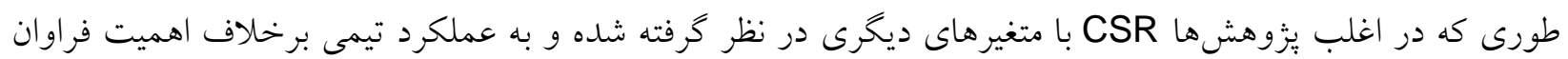
آن توجهى نشده است. در اندى تحقيقات انجام شده نيز، امتيازات و نتايج تيمها به عنوان عملكرد تيمى در نظر كرفته

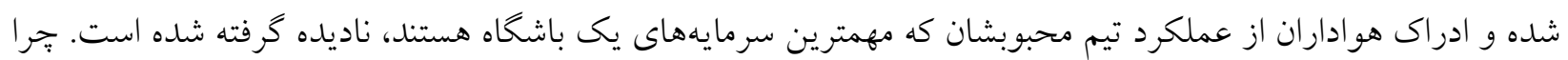
كه ممكن است با وجود كسب نتيجهُ مطلوب و يا ارتقاء امتيازات تيم، هواداران به دلايل مختلفى عملكرد تيمشان را مثبت ارزيابى نكنند. همجنين مشخص گرديد در بيشتر تحقيقات انجام شده، متغيرهاى شهرت سازمانى و مزيت رقابتى در نقش متغير وابسته (ملاك) با مسئوليت اجتماعى مورد بررسى قرار كرفتهاند. البته در برخى از مطالعات كه نقش ميانجى را هم داشتهاند، متغيرهاى مستقل و وابستهُ آنها متفاوت و غير از مسئوليت اجتماعى و عملكرد تيمى بوده است. البته اخيراً نيز

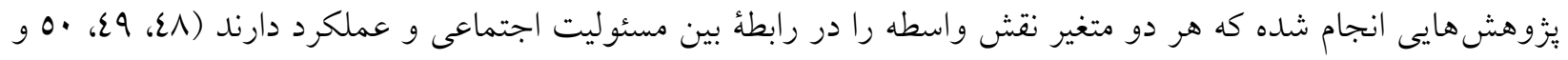
(0)؛ اما اين تحقيقات عمدتاً در صنعت تجارت، بانكدارى و بيمه بوده و عملكرد مالى سازمانها را مورد بروسى قرار دادهاند و به عملكرد تيمى توجه نشده است. به طورى كه ييشنهاد كردهاند، اين نوع تحقيقات در زمينه خدمات نيز صورت كَيرد. يس به نوعى مى توان كفت براى كسب نتايج بهتر، متغيرهاى مزيت رقابتى و شهرت سازمانى در مطالعات جديد بايد بررسى شوند (Or). بنابر اين، فقدان مطالعه در مورد تأثير مسئوليت اجتماعى بر عملكرد تيمى با نقش ميانجى متغيرهاى

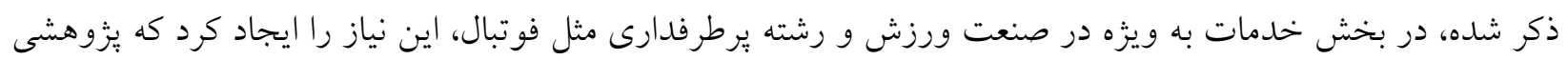
در اين موضوع انجام كيرد؛ كه اين موضوع خود دليلى بر اهميت و ضرورت اجراى تحقيق فعلى بوده و بر جنبه نو بودن آن صحه مى گذارد. به طورى كه اخر به جنين موضوع مهم و ارتباط آن با عملكرد تيمى از ديد هواداران توجه نشوده،

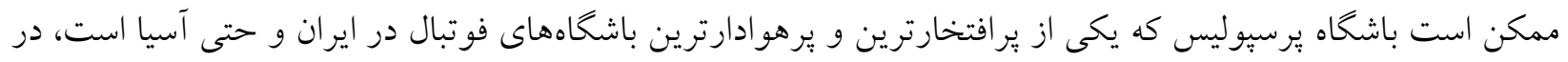

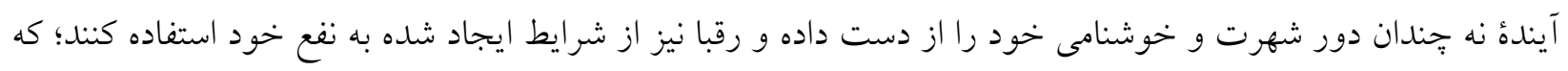


نتيجهُ نهايى آن كاهش عملكرد تيم از ديد هواداران خواهد بود. بنابراين، محقق در نظر دارد نقش ميانجى هريك از متغيرهاى مزيت رقابتى و شهرت سازمانى را در رابطةٌ علّى مسئوليت اجتماعى بر عملكرد تيمى را از نظر هو اداران باشخاه

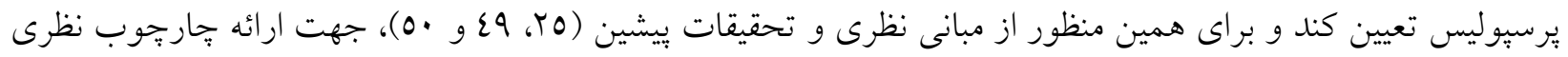
استفاده مىشود:

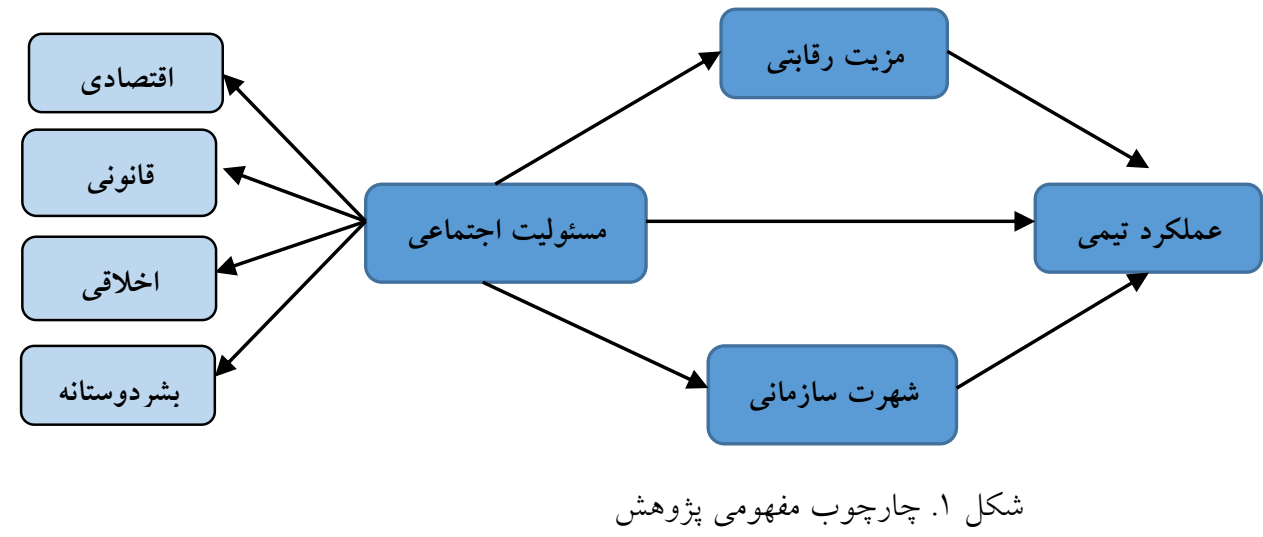

روش

روششناسى يزوهش حاضر توصيفى - ييمايشى بوده و با توجه به هدف از نوع مطالعات كاربردى و با رويكرد معادلات ساختارى مىباشد. جامعه آمارى يُزوهش حاضر را كليئ هواداران باشخاه يرسبوليس كه حداقل يكى بار در سال سابقهُ حضور در ورزشگاه محل بركزارى مسابقات و يا تمرينات تيم يرسبوليس را داشتند، تشكيل دادند. مبتنى بر جدول مور گان در خصوص حجم نمونه آمارى براى جوامع نامحدود عمب نقر به روش نمونه گيرى تصادفى انتخاب شدند؛ كه در اين يزٔوهش با توجه به امكانات محقق در خصوص دستيابى به حجم نمونه بيشتر، تعداد 90ب برسشنامه تكميل و مورد تجزيه و تحليل قرار گرفت. لازم به ذكر است كه يرسشنامهها به صورت الكترونيكى طراحى و در شبكههاى مجازى (تلكرام و اينستاگرام) مربوط به هواداران يرسيوليس توزيع گرديدند؛ به طورى كه هواداران نظراتشان را در قالب گويههاى طراحى (برى

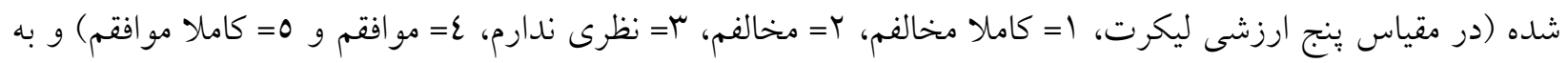

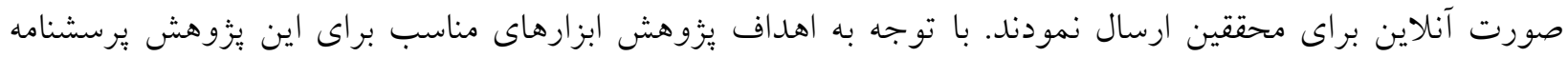

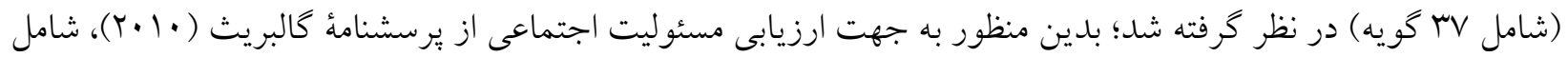
9 كويه در جهار بعد (اقتصادى، قانونى، اخلاقى و بشردوستانه)؛ جهت ارزيابى عملكرد تيمى ·ل گويه بركرفته از

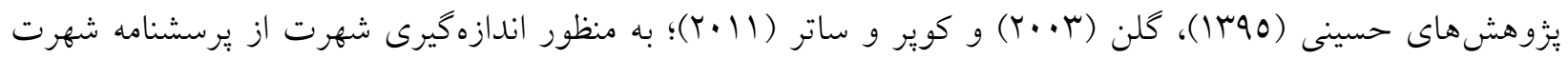

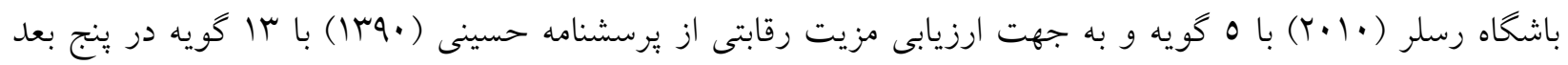


مزيتهاى مشهود، يايدار، يويا، متجانس و مركب استفاده شد (0r، 01، 00، 07، O و 01). روايى صورى و محتوايى ابزارها يس از انجام ترجمه سه مرحلهاى' به تأييد ·ل تن از صاحبنظران حيطهُ مديريت ورزشى رسيد. همجنين، علاوه بر سؤ الات مربوط به هريك از متغيرهاى يزؤهش فرمى نيز مربوط به اطلاعات جمعيت شناختى نمونه آمارى كه دربر گيرنده

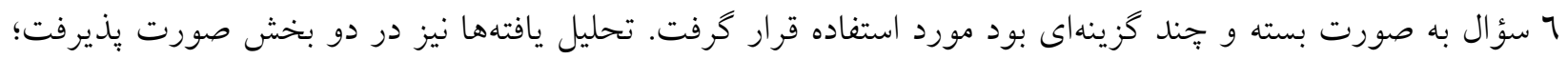

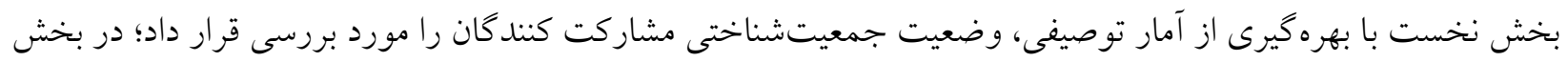
مربوط به آمار استنباطى (بخش دوم) نيز جهت بررسى و تحليل دادهها، با استفاده از رويكرد مدلسازى معادلات ساختارى در هر دو بخش مدل بيرونى (مدل اندازه گيرى) و مدل درونى (مدل ساختارى)، يافتها مورد ارزيابى قرار كرفتند. شايان ذكر است كه در تحليل نتايج از نرم افزارهاى SPSS و SPS 32 S بهره كرفته شد.

\section{يافتهها}

در بخش توصيفى اطلاعات جمعيتشناختى هواداران مورد بررسى قرار كرفت. براى سنجش وضعيت جمعيتشناختى اعضاى نمونه شش سوال مطرح شد كه نتايج آن در جدول ا كزارش شده است. جدول ا. ويزَكى هاى جمعيت شناختى نمونه يزوهش

\begin{tabular}{|c|c|c|c|c|c|}
\hline درصد & \multicolumn{2}{|c|}{ مؤلفه هاى جمعيت شناختى } & درصد & \multicolumn{2}{|c|}{ مؤلفههاى جمعيت شناختى } \\
\hline$r \varepsilon / 1$ & دانشجو & \multirow{4}{*}{ 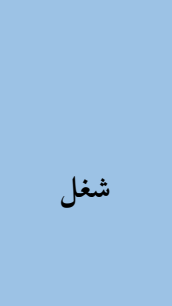 } & $7 / 7$ & $r \cdot-1 \Lambda$ & \multirow{4}{*}{ سن } \\
\hline$\varepsilon 0 / \wedge$ & آزاد & & $\mathrm{rV} / \Lambda$ & $\varepsilon \cdot-\mu_{1}$ & \\
\hline$r Y / \cdot$ & 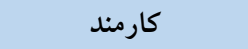 & & $r / r$ & $0 .-\varepsilon 1$ & \\
\hline $9 / 1$ & بيكار & & $\cdot / \mu$ & بالاى 0.0 & \\
\hline$r \varepsilon / \Lambda$ & يك بار در سال & \multirow{3}{*}{ دفعات حضور } & $7 \cdot / 0$ & مجرد & \multirow[b]{2}{*}{ تأهل } \\
\hline rN/O & r-ه بار درسال & & $\mathrm{rq} / \mathrm{o}$ & متأهل & \\
\hline $\mathrm{ru} / \mathrm{v}$ & بيش از 0 بار در سال & & $r \cdot / 1$ & ديبلم & \multirow{4}{*}{ تحصيلات } \\
\hline$\cdot / \wedge$ & كمتر از يك سال & \multirow{3}{*}{ سابقهُ هو ادارى } & $I V / Y$ & كار دانى & \\
\hline$r / \Lambda$ & بين 0-Y سال & & $\mathrm{ru} / \mathrm{v}$ & كارشناسى & \\
\hline $90 / 9$ & بيش از 0 سال & & $10 / 9$ & كارشناسى ارشد و بالاتر & \\
\hline
\end{tabular}


با توجه به نتايج آزمون K.S (جدول Y) جنين نتيجه گيرى مى شود كه با توجه به اينكه هر سه متغير داراى سطح معنادارى

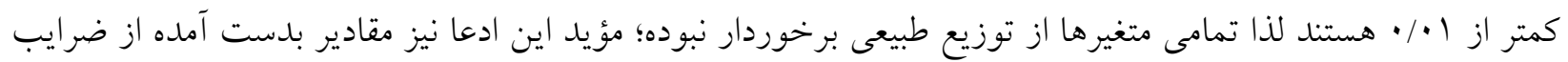

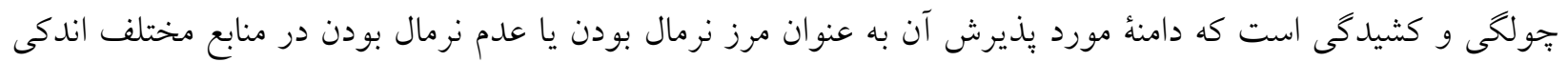

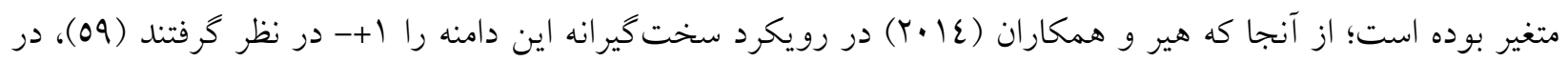
اين تحقيق نيز اين حد نصاب به عنوان ملاك مد نظر قرار كرفت. از اينرو باتوجه به نتايج اين آزمونها به منظور آزمودن

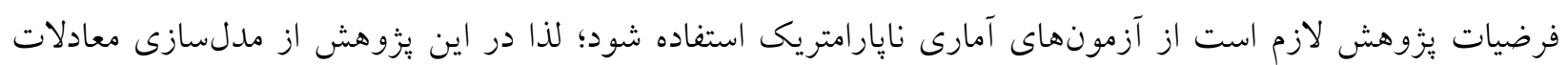
ساختارى واريانس محور به منظور آزمون فرضيات تحقيق استفاده كرديد. مدلسازى معادلات ساختارى واريانس محور از دو مرحلهُ اصلى تشكيل شده است؛ () مدل اندازهكيرى (مدل بيرونى)؛

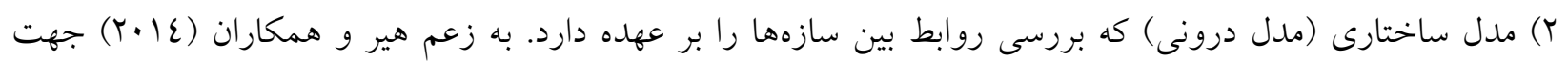
ارزيابى هر يك از مراحل، شاخصهايى در نظر خرفته شده است (09).

\begin{tabular}{|c|c|c|c|c|}
\hline كشيدگى & جولنى & سطح معنادارى & آماره آزمون & متغير \\
\hline$-1 / \varepsilon$. & $1 / \pi \varepsilon$ & $\cdot / \cdots 1$ & $\% \cdot \mathrm{VO}_{0}$ & مسئوليت اجتماعى \\
\hline$-1 / \pi V$ & $r / 91$ &.$/ \cdot 1$ & ./Tro & عملكرد تيمى \\
\hline$-1 / 710$ & $1 / \cdot v \varepsilon$ &.$/ \cdot 1$ & .11 .9 & شهرت سازمانى \\
\hline $1 / \cdot 11$ & $-1 / 2 V$ &.$\cdots 1$ & 每 & مزيت رقابتى \\
\hline
\end{tabular}

\section{تحليل مدل بيرونى}

بارهاى عاملى از طريق محاسبه مقدار همبستكى شاخصهيل مدولى يكى سازه با آن سازه محاسبه مىشوند كه طبق كفتهٔ هير و همكاران (عا • (Y) حداقل ملاكى قابل قبول براى بارهاى عاملى ع/· • به بالا در نظر گرفته شده است (09). با توجه به نتايج

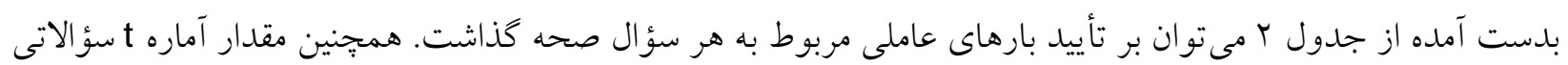
كه بارهاى عاملى مناسبى كسب كرده بودند نيز از آنجا كه در دامنهى 1/97+- نبودند (و يا به عبارتى بيشتر از اين مقدار بدست آمدند) معنادارى آنها نيز مورد تأييد قرار گرفت. نتايج كامل در جدول ذيل قابل مشاهده است (جدول مان). 


\begin{tabular}{|c|c|c|c|}
\hline t t t t t & بار عاملى & آيتم & متغير \\
\hline \multicolumn{4}{|c|}{ عملكرد تيمى } \\
\hline$r T / \mu \Lambda$ & . $/ 0$ rs & $\mathrm{P} 1$ & \\
\hline $1 . / 11$ & $.10 \cdot 0$ & $\mathrm{P} 2$ & \\
\hline $9 / 40$ & $.10 \cdot 0$ & P3 & \\
\hline $1 / 70$ & $\cdot / \varepsilon \wedge r$ & P4 & \\
\hline $7 / 91$ & $\cdot / \varepsilon r$. & P5 & \\
\hline N/Or &.$/ 0 r 1$ & P6 & \\
\hline$r Y / \cdot V$ & . NIT & P7 & \\
\hline $10 / 00$ & $\cdot / 7 \uparrow$ & P8 & \\
\hline$T / / \mu_{T}$ &.$/ 79$ & P9 & \\
\hline $11 / 70$ & $\cdot / v \varepsilon q$ & P10 & \\
\hline \multicolumn{4}{|c|}{ مسئوليت اجتماعى } \\
\hline TN/9A & $\cdot / \wedge \varepsilon 7$ & CSR_L & مسئوليت قانونى \\
\hline$r N / \varepsilon q$ & $\cdot / N Y \varepsilon$ & CSR_E & مسئوليت اقتصادى \\
\hline$r_{\Lambda /} \cdot \Lambda$ & $\cdot / 1 \cdot 0$ & CSR_ET & مسئوليت اخلاقى \\
\hline$T r / T V$ & $\cdot / N V q$ & CSR_F & مسئوليت بشردوستانه \\
\hline \multicolumn{4}{|c|}{ شهرت } \\
\hline$r \xi / \cdot r$ & $\cdot / \mathrm{VNI}$ & $\mathrm{R} 1$ & \\
\hline ro/lE & $\cdot / v \cdot 1$ & $\mathrm{R} 2$ & \\
\hline ro/ar & $\cdot / N \pi 7$ & R3 & \\
\hline$V / r T^{\prime}$ & $\cdot / \varepsilon \varepsilon \wedge$ & R4 & \\
\hline$r \varepsilon / \varepsilon r$ & $\cdot / N T I$ & R5 & \\
\hline \multicolumn{4}{|c|}{ مزيت رقابتى } \\
\hline$r q / 7 q$ & $\cdot / \mathrm{VVq}$ & C_A_obvious & مشهود \\
\hline or/or & $\cdot / \wedge \varepsilon \wedge$ & C_A_Stable & لي بـايدار \\
\hline$\wedge 7 / 79$ & $\cdot / \mathrm{MM}$ & C_A_Dynamic & يويا \\
\hline$\{r / 7\}$ & $\cdot / \Lambda \cdot \Lambda$ & C_A_Congruent & متجانس \\
\hline $7 \cdot / \cdot 1$ & 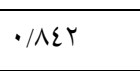 & C_A_Compound & 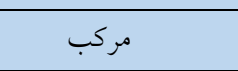 \\
\hline
\end{tabular}

https://jrsm.khu.ac.ir/ 
جدول ع. ادامه ارزيابى قابليت تحليل مدل بيرونى

\begin{tabular}{|c|c|c|c|}
\hline ميانغين واريانس استخرارج شده & جايايى تركيبى & آلفاى كرونباخ & \\
\hline.$/ 0 r$. & $\cdot /$ Arq & ·VAV & عملكرد تيمى \\
\hline$\cdot / 7 r \varepsilon$ & $\cdot / 179$ & $\cdot /$ VA1 & مسئوليت اجتماعى \\
\hline .1014 & $\cdot / \mathrm{AlT}$ & $\cdot / 211$ & شهرت سازمانى \\
\hline.$/ 790$ &.$/ 919$ & $\cdot / \wedge q$. & مزيت رقابتى \\
\hline
\end{tabular}

در بخش مربوط به ارزيابى قابليت اعتماد يرسشنامهها (يكى ديخر از الزامات تأييد مدل بيرونى) از دو روش آمارى ضريب آلفاى كرونباخ جهت ارزيابى همسانى درونى برسشنامها و روش بايايى تركيبى يا بايايى سازه برسشنامهها استفاده شد. كه نتايج هر دوى اين آزمونها مناسب برآورد شدند (بالاتر نقطه برش مدنظر V/•). در مدلسازى معادلات ساختارى شاخص متوسط واريانس استخراجشده جهت ارزيابى قابليت اعتبار همخرا در سطح عامل مورد استفاده قرار مى گيرد. نقطه

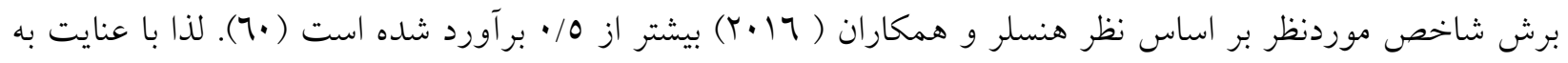
اين امر و با توجه به نتايج جدول فوق مىتوان شرط اعتبار همخرا در سطح عاملها را مورد تأييد قرار داد. در بخش ارزيابى روايى واخرا'ى متغيرهاى تحقيق به منظور اطمينان از اعتبار مميز، بايستى ميانخين واريانس استخراج

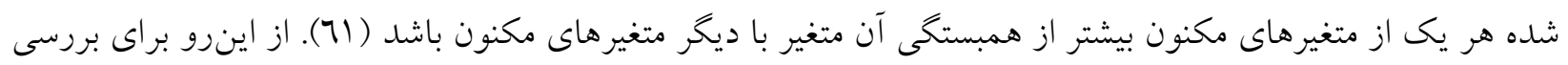

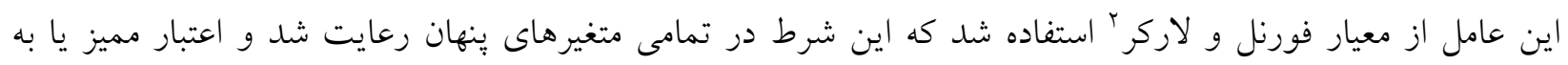

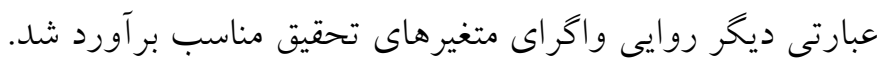

جدول 0. نتايج ارزيابى روايى واخرا متغيرهاى بنهان

\begin{tabular}{|c|c|c|c|c|}
\hline$\varepsilon$ & r & $r$ & 1 & \\
\hline & & & $\cdot / \mathrm{V} 10$ & 1. شهرت \\
\hline & & $\cdot / \mathrm{YM}$ & $\cdot / 299$ & r. عملكرد تيمى \\
\hline & - IAMT & $\cdot / 2 \cdot 9$ &.$/ 0 T_{1}$ & r. عملكرد تيمى \\
\hline •/V^A &.$/ 717$ & $\cdot / \varepsilon r \tau$ & $\cdot 10 \mathrm{VO}$ & ع. مسئوليت اجتماعى \\
\hline
\end{tabular}

1. Discriminant Validity

2. Fornell-Larcker 


\section{مدل درونى (مدل ساختارى)}

يس از تأييد قابليت اعتماد مدل بيرونى، گام بعدى ارزيابى نتايج مدل ساختارى است كه اين امر شامل بررسى قابليتهاى بيشبينى مدل و روابط بين سازههاست كه با استفاده از يك رويكرد نظامند در قالب كامهايى بر اساس بيشنهاد هير و

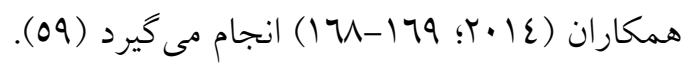

به منظور ارزيابى همخطى بين عامل هاى از شاخص عامل تورم واريانس استفاده شد. بر اساس نظر هير و همكاران (ع (Y) نقطه برش ه آستانهى تحمل در نظر كرفته شده براى برآورد و تشخيص ميزان همخطى بين متغيرها در نظر كرفته شده

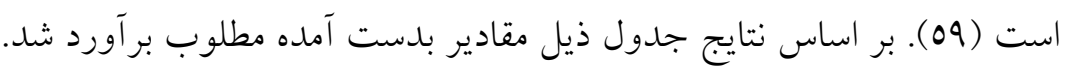
جدول 7. ارزيابى همخطى بين متغيرها

\begin{tabular}{|c|c|c|c|}
\hline \multicolumn{2}{|c|}{ متغيرهاى وابسته } & & \\
\hline مزيت رقابتى & عملكرد تيمى & شهرت & \\
\hline VIF & VIF & VIF & شاخص عامل تورم واريانس \\
\hline & T/ITV & & شهرت \\
\hline & 1/17V & & مزيت رقابتى \\
\hline 1 & $r / .77$ & 1 & مسئوليت اجتماعى \\
\hline
\end{tabular}

كام بعدى ارزيابى ضرايب مسير و معنادارى روابط بين متغيرها در مدل ساختارى است كه اطلاعات آن در جدول V قابل مشاهده است.

جدول V. نتايج ارزيابى اثرات مستقيم و غيرمستقيم هر يك از متغيرها

\begin{tabular}{|c|c|c|c|c|c|c|c|}
\hline 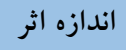 & \multicolumn{3}{|c|}{ اثرات غير مستقيم } & \multicolumn{3}{|c|}{ 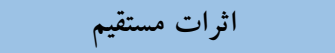 } & \multirow[t]{2}{*}{ 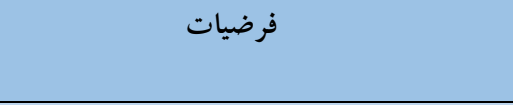 } \\
\hline$f^{2}$ & $\mathrm{P}$ & $\mathrm{T}$ & $\beta$ & $\mathrm{P}$ & $\mathrm{T}$ & $\beta$ & \\
\hline 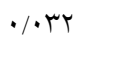 & & & & $\bullet \cdot \varepsilon$ & 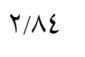 & $\cdot / r 1$ & شهرت سازمانى > عملكرد تيمى \\
\hline$\cdot / \cdot 11$ & & & & $\cdot / 701$ & . /20Y & $\cdot / \cdot r$ & مزيت رقابتى > عملكرد تيمى \\
\hline$\cdot / \Lambda r^{\prime}$ & & & & $\cdot \cdots$ & rT/VO & $\cdot / 7 V_{0}$ & مسئوليت اجتماعى > شهرت سازمانى \\
\hline.$/ 11 \mathrm{~V}$ & & & & $\cdot \cdots$ & $7 / 9$. & $\cdot / r 99$ & مسئوليت اجتماعى > عملكرد تيمى \\
\hline$\cdot / 71 \%$ & & & & $\bullet \cdots$ & ry/01 & $\cdot / 717$ & مسئوليت اجتماعى > مزيت رقابتى \\
\hline & $\cdot / \cdot 0$ & $r / \Lambda \cdot \Lambda$ & $\cdot / \ell \xi T$ & & & & مسئوليت اجتماعى > شهرت > عملكرد تيمى \\
\hline & $\cdot / 70 Y$ & $\cdot / 201$ &.$/ \cdot 11$ & & & & مسئوليت اجتماعى > مزيت > عملكرد تيمى \\
\hline
\end{tabular}

https://jrsm.khu.ac.ir/ 
بر اساس جدول فوق نتايج حاكى از آن بود كه از بين فرضيه هاى اصلى بزوهش به صورت اثرات مستقيم و غير مستقيم

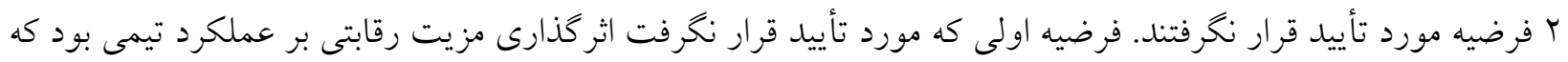
اين مسير با ضريب ץ•/ • معنادار بلدست نيامد؛ همجنين يكى از فرضياتى كه نقش ميانجى را نيز مورد بررسى قرار داده

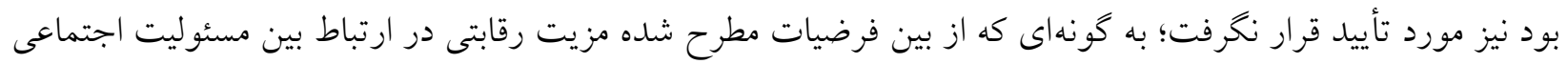
و عملكرد تيمى بدليل ضريب مسير ضعيف 11 • • • معنادار گزارش نشد. با اين وجود ديخر نقش ميانجى مفروض در اين

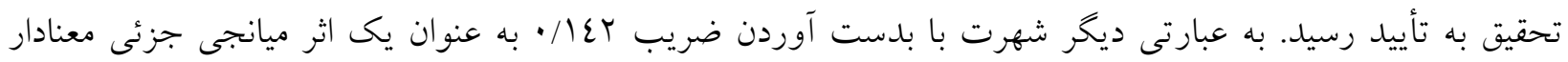

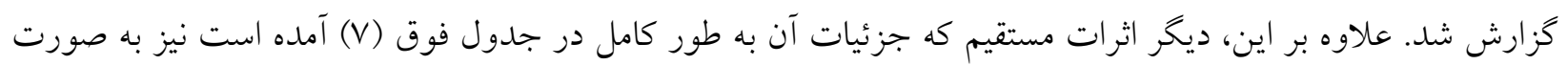
معنادار به تأييد رسيدند.

شاخص ديخرى كه در جدول فوق مورد بررسى قرار كرفت، شاخصى بنام اندازه اثر ff (اندازه اثركوهن ') بود. اين شاخص

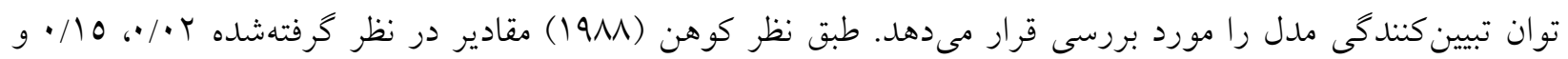

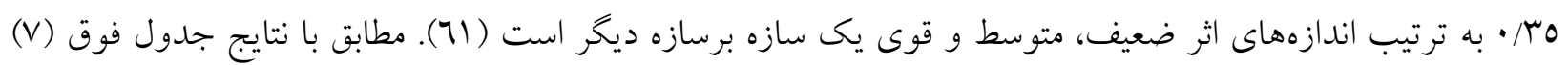

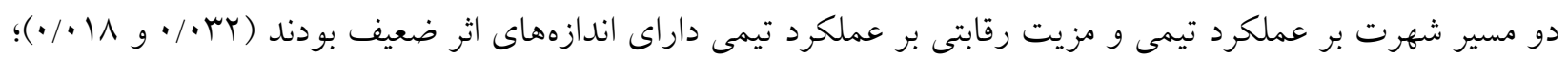

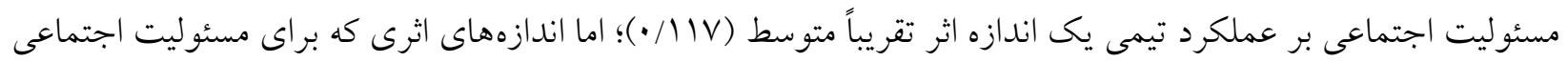

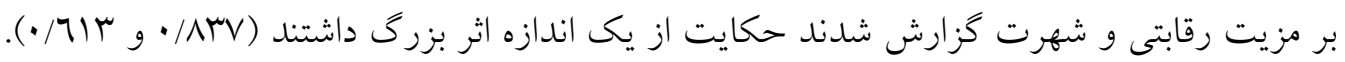

جدول ^. شاخصهاى ارزيابى مدل ساختارى

\begin{tabular}{|c|c|c|c|}
\hline مزيت رقابتى & عملكرد تيمى & شهرت & \\
\hline$\cdot r \wedge$. & $\cdot \pi \varepsilon$. &.$/ 207$ & ضريب تعيين \\
\hline$\cdot / \pi\{7$ & .11 .0 & $\cdot / T \cdot r$ & توان بيش بينى \\
\hline
\end{tabular}

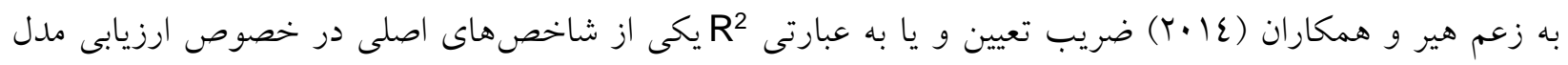
ساختارى در رويكرد واريانس محور است. دامنهُ تصميم گيرى در خصوص ارزيابى ضريب تعيين براى هر متغير ملاكى

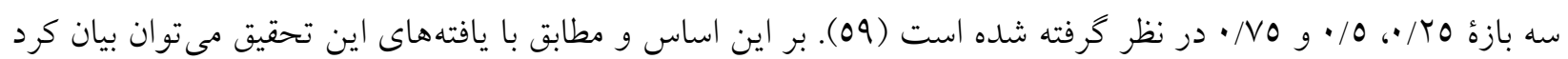

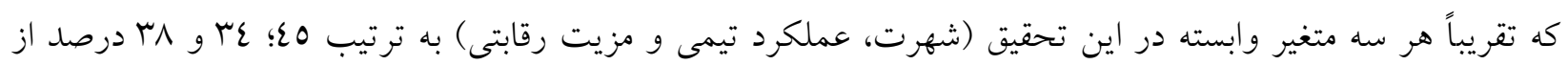
واريانس آنها توسط متغيرهاى مستقل تبيين شدند. مطابق با اين نتايج مىتوان اظهار داشت كه هر سه متغير به عنوان ضرايب تبيين متوسط گزارش شدند.

1. Effect Size Cohen

https://jrsm.khu.ac.ir/ 
توان يِيش بينى كنند كى مدل، Q2 (شاخص استون كايسر ') معيار ديخرى جهت ارزيابى مدل ساختارى است. اين شاخص

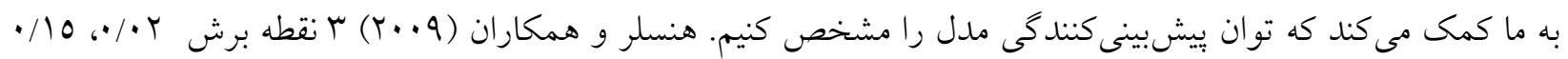

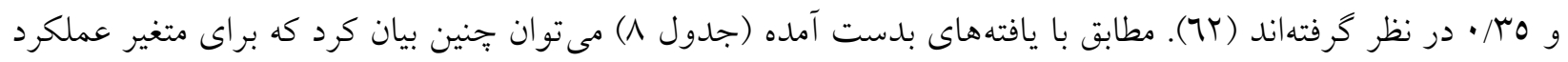

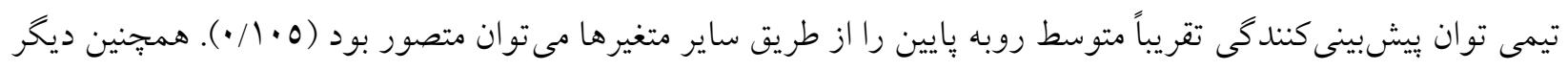

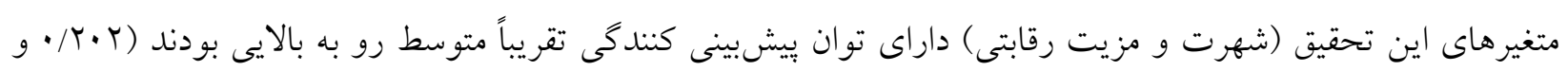

در نهايت يس از بررسى شاخصهاى متعدد در خصوص ارزيابى هريك از بخشهاى مدل سازى معادلات ساختارى (اعم از مدل بيرونى و مدل درونى) هير و همكاران (Y.17) جهت ارزيابى كلى مدل معيارى را تحت عنوان شاخص اصلى كلى نيكويى برازش در مدلسازى معادلات ساختارى در رويكرد واريانس محور معرفى كردند كه در اصطلاح به ريشه ميانحين

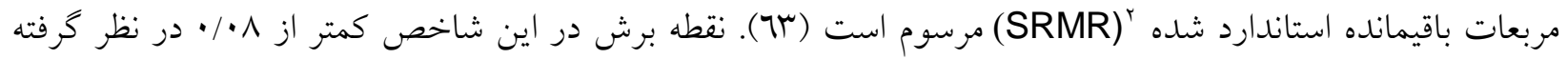
شده است؛ كه در اين بززوهش اين نقطه برش نيز رعايت شد.

جدول 9. ارزيابى كنترل كيفيت كلى مدل معادله ساختارى

\begin{tabular}{|c|c|}
\hline مقادير بدست آمده & شاخص \\
\hline$\cdot / \cdot V r$ & SRMR \\
\hline
\end{tabular}

1. Stone Geisser's

2. Standardized Root Mean Square Residual (SRMR)

https://jrsm.khu.ac.ir/ 


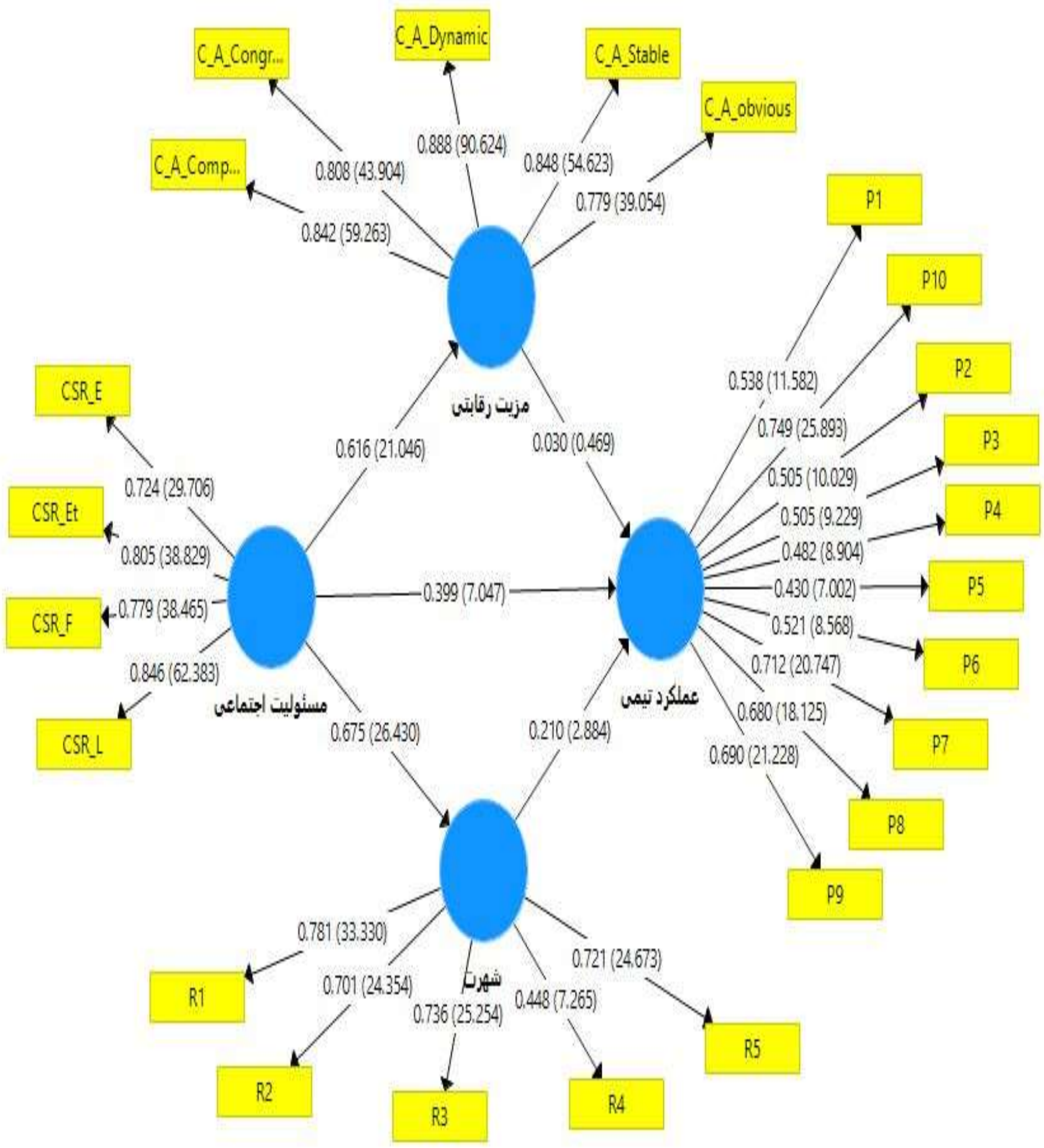

Smart PLS شكل r. خروجى نرم افزار 3

https://jrsm.khu.ac.ir/ 
يُوهش حاضر با هدف تعيين نقش ميانجى مزيت رقابتى و شهرت سازمانى در رابطةٌ علّى مسئوليت اجتماعى و عملكرد تيمى باشخاه يُسبوليس انجام شد. بدين منظور 90ب يرسشنامه توسط هواداران تكميل و مورد بررسى قرار كرفت. براساس نتايج حاصل، مسئوليت اجتماعى بر عملكرد تيمى باشگاه برسبوليس تأثير مثبت و معنادار دارد؛ كه اين يافته با نتايج

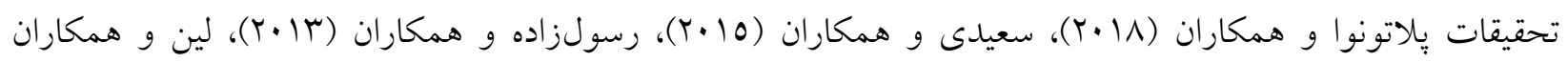

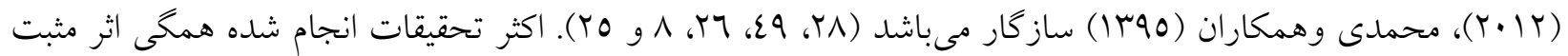
مسئوليت اجتماعى بر متغير عملكرد را كزارش كردهاند. البته يافتهاى تحقيق اييرل، كارول و هاتفيلد (1910) و نلينگ و

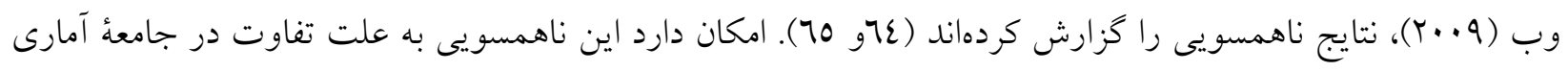

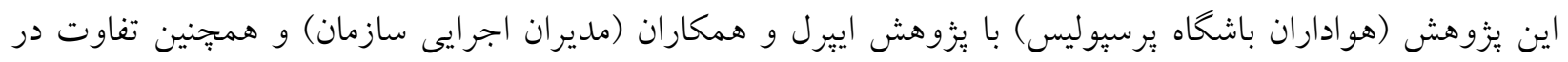
زمان و نحوه اندازه گيرى متغير عملكرد در يزوهش حاضر (عملكرد تيمى ادراك شده هواداران) با تحقيق نلينگ و وب

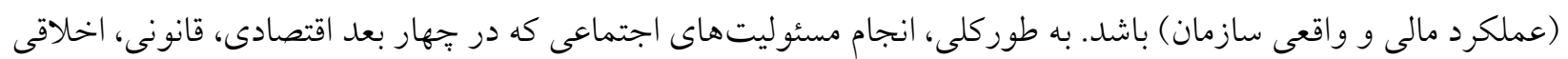
و بشردوستانه انجام مى شود، عملكرد تيم را تحت تأثير قرار مىدهد و موجب مى شود هو اداران برسبوليس درى مثبتى از

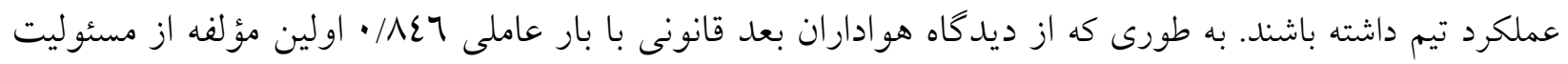
اجتماعى است كه باشخاه يرسيوليس بايد به آن توجه داشته باشد؛ جرا كه موجب ارتقاء عملكرد تيم محبوبشان مىشود. در همه جوامع و سازمانها به اهميت قانون و توجه به آن اشاره شده است و باشخاه برسبوليس نيز به عنوان بخشى از اين جامعه و به عنوان سازمان ورزشى برطرفدار لازم است احترام به قوانين را سرلوحه اقدامات باشگاه قرار دهد. به طورى كه ييشنهاد مىشود در جهت ارتقاى اين جنبة مهم از مسئوليت اجتماعى، از برنامههاى راهبردى جهت فرهنگ را يادآورى و نحوه اجراى آن را آموزش دهند. از حقوق بازيكنان، مربيان، كادر فنى و حتى هواداران دفاع كند. هنخام اجراى مسابقات با هركونه تبعيض هاى قوميتى و نزادى مبارزه كند. با عو املى كه مسئول حفظ امنيت فضاى مسابقه را دارند، همكارى كنند. آيين نامههاى قابل اجرا جهت جلو كيرى از نقض قانون وضع كنند. اقدامات لازم جهت افزايش ايمنى هواداران را مدنظر قرار دهند. قراردادهاى شفاف و در راستاى مقررات با بازيكنان و مربيان وضع كنند. به مسائل زيست محيطى توجه داشته باشند و برنامههاى باشگاه در راستاى حفظ محيط زيست باشد. بنابراين، مىتوان كفت احترام به قوانين و مقررات توسط باشگاه يرسبوليس موجب تقويت بعد قانونى مسئوليت اجتماعى و در نهايت منجر به افزايش مزيت رقابتى، شهرت سازمانى و عملكرد تيمى باشگاه مىشود. طبق نتايج حاصل بعد اخلاقى (0 •//•) دومين مؤلفه از مسئوليت اجتماعى است كه از نظر هواداران اهميت دارد و بايد مورد توجه قرار كيرد. زيرا باشخاه برسبوليس كه يكى از برهوادارترين باشگاههاى فوتبال در آسيا است، الكوى 
اخلاقى مهمى براى هواداران محسوب مىشود. به طورى كه اقدامات بازيكنان و مربيان توسط طرفداران الكوبردارى مىشود و اين جّه خوب جّه بد اثر خود را بر باشخاه خواهد كذاشت. به همين دليل بيشنهاد مىشود باشگاه اقدامات كسترده و اثركذار در جهت ترويج اصول اخلاقى به كار كيرد و افرادى را كه به اصول اخلاقى بايبندند را تشويق و با كسانى كه اعتقادى به رعايت اين اصول ندارند مقابله كند. هنگام مصاحبه و عقد قرارداد با طرفين صداقت و راستخويى را بيشهُ اعمال خود قرار دهند و عدالت و برابرى را در برابر همگان رعايت كنند. همدٔ افر اد را به احترام و سازش با يكديخر تشويق كنند. جرا كه موجب بايبندى و ترويج اصول اخلاقى در باشخاه و در ميان هواداران و همجنين موجب تمايز و خوشنامى باشخاه در برابر رقبا خواهند شد. به عقيده هواداران باشگاه برسبوليس بعد بشردوستانه (VV9/•) سومين بعد مسئوليت اجتماعى است كه جهت تقويت آن بايد برنامهريزى شود. زيرا هواداران علاقه دارند باشگاه محبوبشان در جامعه جايشاه مناسبى از منظر اجراى فعاليتهاى بشردوستانه داشته باشد تا بتوانند به آن افتخار كنند. به همين علت بيشنهاد مىشود با افراد و سازمانهايى كه در جهت كمك به هم نوعان تلاش مى كنند همكارى داشته باشند. مدارس فوتبال، فضاهاى آموزشى رايخان براى مناطق كم برخوردار ايجاد كنند. بازىهاى دوستانه به نفع افراد بىبضاعت و بيماران انجام دهند و حمايت خود را از آنها اعلام كرده و جامعه را نيز به انجام فعاليتهاى بشردوستانه تشويق كنند و از اين طريق حمايت جامعه را كسب كرده و عملكرد تيمى باشگاه را از ديد هواداران ارتقاء بخشند. برخلاف هرم كارول، از نظر هواداران باشگاه يرسيوليس بعد اقتصادى (201/) نسبت به ابعاد ديخر از اهميت كمترى برخوردار است. ممكن است به اين دليل باشد كه هواداران عملكرد باشغاه را همانند سازمانهاى تجارى صرفاً با سودآورى و درآمد بالاى مالى برى بردي آن نمىسنجند و حتى اين نتيجه مىتواند نوعى هشدارى براى مديران باشگاه يرسبوليس باشد كه هواداران از عملكرد اقتصادى باشخاه رضايت كمترى دارند. دليل آن را نيز مىتوان شفاف نبودن درآمدها و هزينهاى باشخاه دانست. به همين دليل بيشنهاد مىشود با سازمانها و اسيانسرهاى با عملكرد مالى و سودآورى بالا قراردادهاى بلند مدت داشته باشند. هزينها و درآمدهاى باشگاه را شفافسازى كرده و اعلام كنند. در جهت تقويت بليت فروشى و مبارزه با بازارسياه و سودجويان اقدامات اساسى صورت كيرد. زيرا اخر بعد اقتصادى باشگاه دجار ضعف شود شهرت باشخاه به خطر خواهد افتاد. نتايج مدل ساختارى تأثير مستقيم، مثبت و قوى مسئوليت اجتماعى بر شهرت سازمانى را نيز تأييد كردند. همجنين يافته هاى

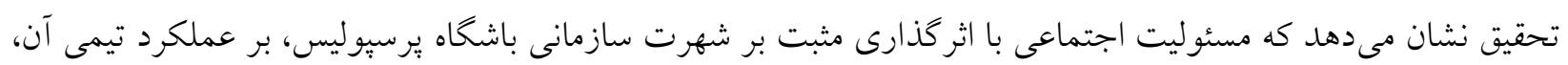

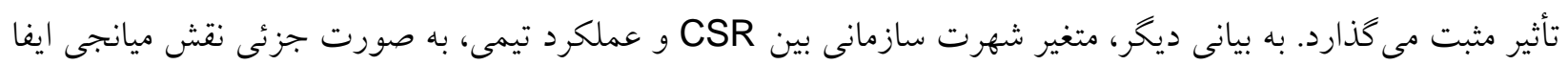
مى كند. اثر كذارى مستقيم و مثبت مسئوليت اجتماعى بر شهرت سازمانى و يا نقش ميانجى شهرت سازمانى در تحقيقات 


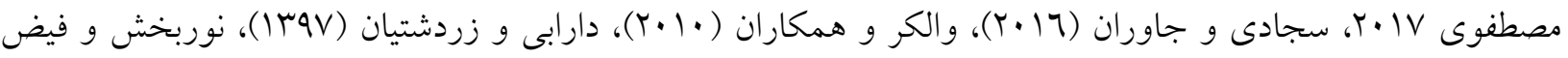

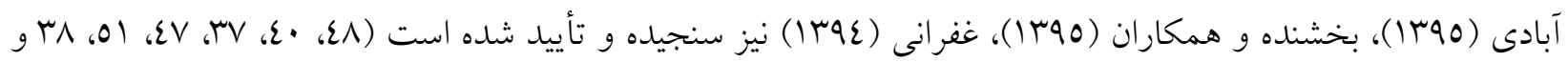
q"). تحقيقات ذكر شده در حيطههاى مختلف اعم از بانكدارى، تجارت و ورزش انجام شدهاند. اما همكى تأثير قوى و مثبت مسئوليت اجتماعى بر شهرت سازمانى را تأييد كردند كه نشان از اهميت شهرت سازمانى در حيطههاى مختلف

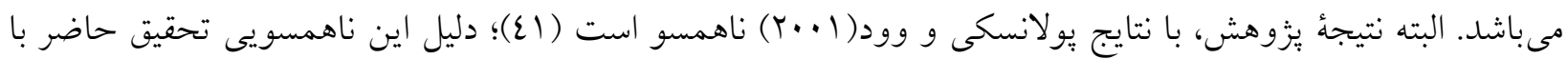
تحقيق يولانسكى ممكن است اين باشد كه تحقيق مذكور در حيطهُ تجارى و در شرايط خاص انجام شده است و اين مى تواند ناشى از تفاوت حيطهُ ورزش با تجارت باشد كه گاهى بر نتيجه يزوهش اثر مى كذارد.

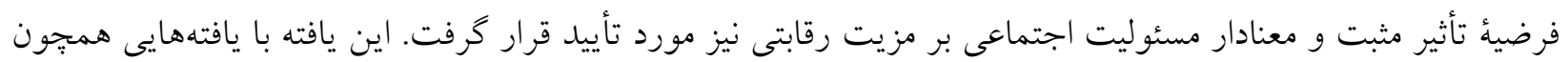

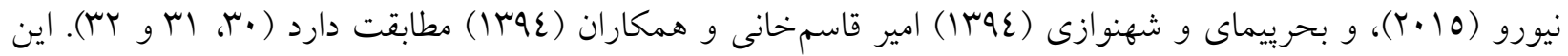
تحقيقات و يزوهش حاضر در تأثير مثبت اجراى برنامهاى مسئوليت اجتماعى براى كسب مزيت رقابتى سازمانها، اتفاق نظر دارند. البته نقش ميانجى مزيت رقابتى در اثر گذارى مسئوليت اجتماعى بر عملكرد تيمى مورد تأييد واقع نشد. و اين

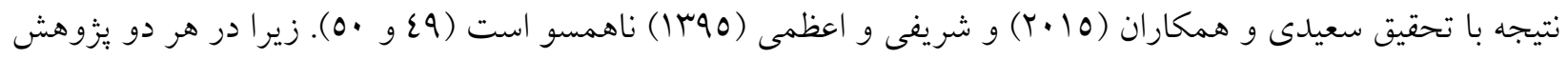
نقش مزيت رقابتى به عنوان ميانجى در تأثير مسئوليت اجتماعى بر عملكرد سازمانى تأييد شده است. گمان مىرود دليل اين مغايرت سنجش عملكرد واقعى در بزووهشهاى قبلى و سنجش عملكرد ادراك شده هواداران در اين تحقيق باشد. بر اساس اينكه مسئوليت اجتماعى بر شهرت سازمانى و مزيت رقابتى اثر مثبت و مستقيم دارد، باشخاه برسبوليس مىتواند با

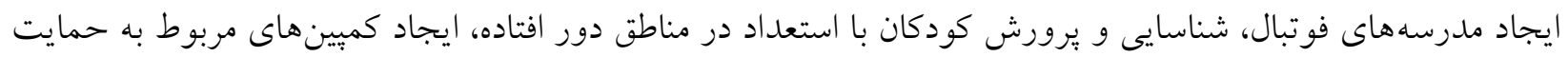
از محيط زيست، برهيز از مصاديق تبعيض قوميتى كه نوعى از فعاليتهاى مسئوليت اجتماعى محسوب مىشوند، ديدكاه مثتى از فعاليتهاى باشخاه در ميان هواداران ايجاد كند و موجب افزايش شهرت باشكاه شود و از رقبايش متمايز شود، و اين موضوع موجب مىشود ضعفهاى باشگاه در خصوص ابعاد مزيت رقابتى جبران شود. به عنوان مثال اخر كمبودى در

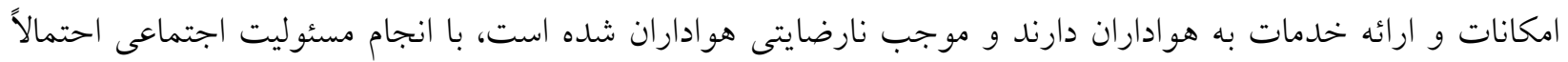
بتوانند بخشى از كاستى ها را جبران كنند.

در اين يزوهش انتظار مىرفت كه متغير مزيت رقابتى به طور مستقيم و غير مستقيم (نقش ميانجى) بر عملكرد تيمى باشخاه يرسيوليس اثر مثبت و معنادار داشته باشد، اما نتايج حاكى از رد اين فرضيه است. به طورى كه با يزوهشهاى صورت كرفته (919، ساب، عس و 77) ناساز گار است. شايد دليل تفاوت اين باشد كه يزوهش حاضر براى اولين بار است كه ارتباط مسئوليت اجتماعى با عملكرد تيمى را با متغيرهاى ميانجى مزيت رقابتى و شهرت سازمانى در حيطه ورزش سنجيده است؛ زيرا در اكثر تحقيقات عملكرد مالى و سازمانى مورد سنجش قرار كرفته و در خصوص عملكرد تيمى بزوهشى يافت نشد. حتى ابزار استفاده شده در خصوص مزيت رقابتى با ابزار تحقيقات قبلى متفاوت است. به طور كلى كسب مزيت رقابتى

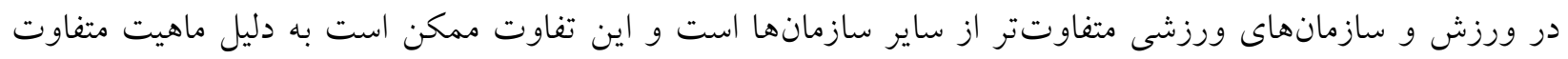


ورزش و سازمانهاى ورزشى باشد. همجنين ممكن است اين مغايرت، به علت تفاوت در نوع ارزيابى و اهميت مزيت كات رقابتى در ميان كشورهاى توسعه يافته با كشورهاى در حال توسعه و توسعه نيافته باشد. تجرا كه در كشورهاى توسعه يافته

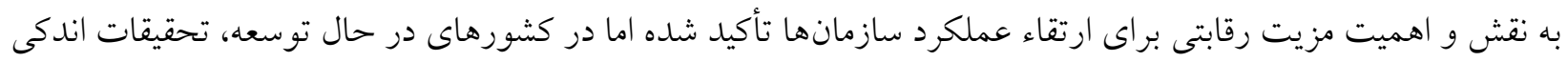
در اين خصوص انجام شده است. بنابراين، محقق مقدور به مقايسه و يا تعميم نتايج يزوهش حاضر با نتايج يزوهشهاى ساير سازمانها نبوده و احتمالاً با انجام تحقيقات بيشتر در آينده بهتر بتوان در اين خصوص اظهارنظر كرد. همجنين احتمال مى رود كه هواداران ديدكاه مثبتى نسبت به متمايز بودن باشگاه يرسبوليس نداشتهاند و اين متغير را در افزايش عملكرد تيم بى تأثير ارزيابى كردهاند. كه اين موضوع مىتواند به سبب تجربههاى ناخوشايند هواداران هنگام حضور در ورزشگاه و

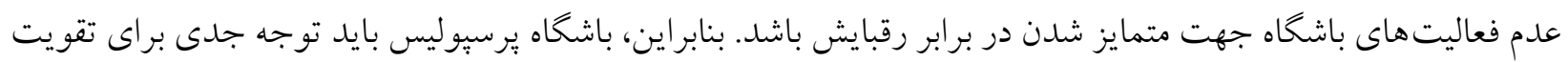
ابعاد مزيت رقابتى داشته باشد. بر همين اساس، بيشنهاد مى شود با ايجاد محيطى دلِيند و خوشايند براى هو اداران، آراسته و مرتب كردن ظاهر ورزشگاه، ارائه خدماتى نوين و همخام با تكنولوزى، باكيفيت، جديد و خلاقانه، با صرف كمترين هزينه و زمان براى هواداران، استفاده از روشهاى متفاوت براى حفظ و جذب هوادار (مثل كانالهاى مجازى)، آموزش مسئولين و كاركنان باشخاه جهت برخورد مناسب با هواداران، ارائه مشاورههاى تخصصى به علاقمندان و هواداران توسط بازيكنان و مربيان باشكاه و منحصر به فرد كردن فضاى باشكاه نسبت به رقبا، هريك از ابعاد مزيت رقابتى را تقويت كرده

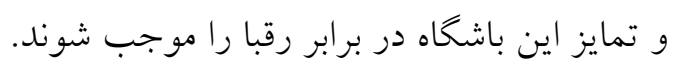
از ديخر انتظاراتى كه در اين يزوهش محقق گرديد، تأثير مثبت و مستقيم متغير شهرت سازمانى بر عملكرد تيمى بود. به

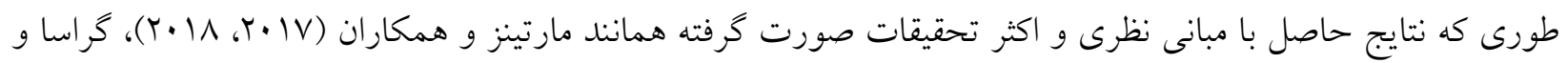

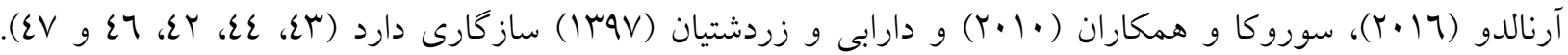
آشكار است كه داشتن عملكرد خوب در هر نوع سازمانى يكى مزيت به شمار مى آيد به طورى كه همه منابع و امكانات موجود در سازمان در جهت رسيدن به يك عملكرد مطلوب مىباشند. در همين راستا شهرت سازمانى به عنوان متغير موثر بر عملكرد تيمى، نقش مسئوليت اجتماعى را در راستاى افزايش عملكرد تيمى تقويت كرده و به عنوان ميانجى عمل مى نمايد. شهرت سازمان از با ارزشترين سرمايههاى يك سازمان است كه منجر به كاهش هزينها و افزايش عملكرد مىشود. بنابر اين، توصيه مى شود باشگاه يرسبوليس نيز به عنوان يكى سازمان ورزشى به نقش و اهميت آن توجه جدى دهى داشته باشد. از همين رو، مديران باشگاه بايد در خلق جشمانداز باشگاه و استراتزىهاى كسب آن هوشمندانه عمل كنند يعنى جشم انداز سازمان در جهت افزايش شهرت باشگاه باشد. به وعدههايى كه به بازيكنان، مربيان و هو اداران دادهاند، به بهترين شكل عمل كنند. با طراحى برنامهها و اقدامات مشخص، به شناسايى و برورش استعدادهاى موجود در زمينهاى داورى، مربيخرى و بازيكن فوتبال بيردازند. با تمركز بر فعاليتهاى خاصى كه كمتر مورد توجه رقبا هستند، موجب متمايز شدن باشگاه از سايرين شوند. زيرا هنگامى كه هواداران ارزيابى مثبتى از فعاليتهاى باشگاه داشته باشند، شهرت و و عملكرد باشخاه نيز از نظرشان ارتقاء خواهد يافت. 
به طور كلى با استناد به تحقيقات بيشين و نتايج تحقيق حاضر مىتوان بيان نمود كه مسئوليت اجتماعى در اكثريت سازمانها موجب خلق شهرت و مزيت رقابتى براى سازمان مىشود و افزايش شهرت نيز سبب بهبود عملكرد سازمان مربوطه مى شود. در اين ميان، توجه به مؤلفههاى مسئوليت اجتماعى خصوصاً بعد قانونى و اخلاقى در اثر كذارى بر مزيت رقابتى، شهرت سازمانى و در نهايت عملكرد تيمى مهمتر به نظر مىرسند و توصيه مىشود مديران و تصميم گيرندكان باشگاه توجه ويزٔاى به آنها داشته باشند. به علاوه، يِيشنهاد مى شود مسئولان باشكاه فعاليتهاى مربوط به مسئوليت

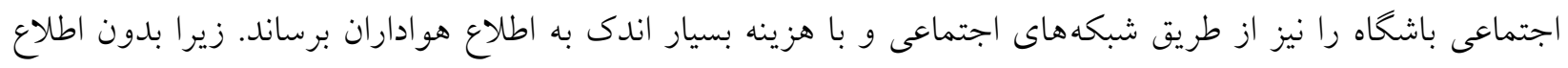
رسانى هر فعاليتى هم انجام شود اثرى نخو اهد داشت.

با توجه به اينكه نتايج يزوهش، محدود به زمان اجراى آن و به صورت مقطعى است و ممكن است كه نظر هواداران يس از كذشت زمان در رابطه با متغيرهاى تحقيق تغيير ييدا كند؛ لذا بيشنهاد مى شود تحقيقات طولى نيز در رابطه با اين موضوع انجام شود. همجنين نتايج حاضر، محدود به كويههاى موجود در برسشنامه مىباشد و به عنوان مثال ويزگى هاى روانشناختى، شر ايط جغر افيايى، فرهنگى و اجتماعى مشاركت كنند كان را كه ممكن است نتيجهُ بزّوهش را تحت تأثير قرار

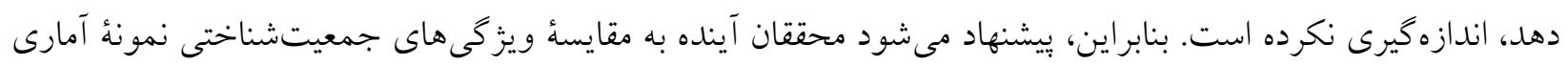
با نتايج حاصل بيردازند. مثلاً تفاوت در تحصيلات، ميزان حضور در ورزشخاه يا سابقهُ هواداراى تا جهه حدى نتيجه.

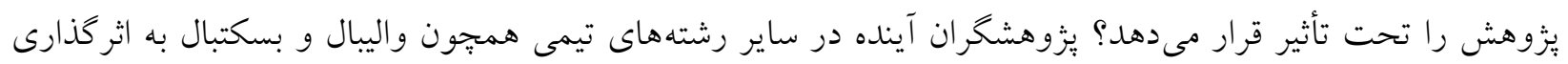

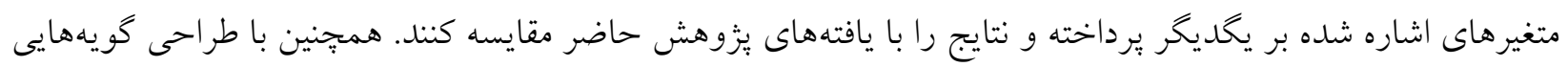

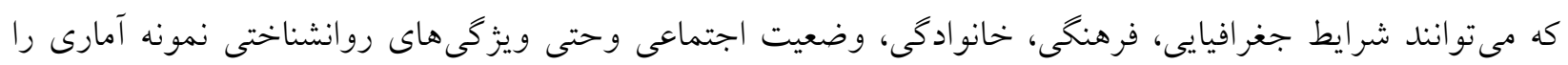
ارزيابى كنند، به يزوهش خود اعتبار بهترى ببخشند.

\section{منابع}

1) Cohen, Aaron; Avrahami, Anat. Soccer fans' motivation as a predictor of participation in soccer-related activies: an empirical examination in israel. Social Behavior and Personality: an international journal, 2005, 33.5: 419-434.

2) Ramezani Nejad, Rahim, Rahmaninia, Farhad, Boroumand Dolagh, Mohammad Reza. Investigating the incidence of aggressive behaviors of Pegah football team players in Iranian professional football league competitions. Journal of Sports Management, 2009; 1 (1): 101-117. (in Persian).

3) Fløtnes, T. G.. Factors of success for Norwegian top football clubs and why profit making is difficult for European football clubs. Copenhagen Business School. M. Sc. Applied Economics and Finance. Mimeo. 2011. Retrieved from http://studenttheses. cbs. dk/handle/10417/2923.

4) Beal DJ, Cohen RR, Burke MJ, McLendon CL. Cohesion and performance in groups: a meta-analytic clarification of construct relations. J Appl Psychol. 2003;88(6):989-1004. doi:10.1037/0021-9010.88.6.989.

5) Audas, Rick; Goddard, John; Rowe, W. Glenn. Modelling employment durations of NHL 
head coaches: turnover and post-succession performance. Managerial and Decision Economics, 2006, 27.4: 293-306.

6) Adler, E. Scott; Berry, Michael J.; Doherty, David. Pushing "reset": The conditional effects of coaching replacements on college football performance. Social Science Quarterly, 2013, 94.1: 1-28.

7) Armstrong, Michael. Performance management (individual, team and organization). Translated by Qelich Lee, Behrooz and Gholamzadeh, Dariush. Publishing Saffar; 2006. (in Persian).

8) Lin, Chieh-Peng; Baruch, Yehuda; SHIH, Wei-Chi. Corporate social responsibility and team performance: The mediating role of team efficacy and team self-esteem. Journal of Business Ethics, 2012, 108.2: 167-180.

9) Walker, Matthew; Kent, Aubrey. Do fans care? Assessing the influence of corporate social responsibility on consumer attitudes in the sport industry. Journal of Sport Management, 2009, 23.6: 743-769.

10) Gond, Jean-Pascal; Crane, Andrew. Corporate social performance disoriented: Saving the lost paradigm?. Business \& Society, 2010, 49.4: 677-703.

11) Ahmadi, Seyed Ali Akbar, Faizabadi, Houria. Investigating Social capital and effect of that on the organization improvement (Case study: Staff Organizations of Tehran municipality). Government Management, 2011; 3 (6): 35-88. (in Persian).

12) Pourfathi, Naghmeh. Social Responsibility Management, National Conference on Organizational Culture, Tehran. 2016. ,,, https://civilica.com/doc/668363. (in Persian).

13) Mcwilliams, Abagail; Siegel, Donald S.; Wright, Patrick M. Corporate social responsibility: Strategic implications. Journal of management studies, 2006, 43.1: 1-18.

14) Caruana, Albert; Ewing, Michael T. How corporate reputation, quality, and value influence online loyalty. Journal of Business Research, 2010, 63.9-10: 1103-1110.

15) Schwaiger, Manfred. Components and parameters of corporate reputation-An empirical study. Schmalenbach business review, 2004, 56.1: 46-71.

16) Miles, Morgan P.; Covin, Jeffrey G. Environmental marketing: A source of reputational, competitive, and financial advantage. Journal of business ethics, 2000, 23.3: 299-311.

17) Ali, I., Rehman, K. U., Yilmaz, A. K., Nazir, S., \& Ali, J. F. Effects of corporate social responsibility on consumer retention in cellular industry of Pakistan. African Journal of Business Management, 2010, 4.4: 475-485.

18) Branco, Manuel Castelo; Rodrigues, Lúcia Lima. Corporate social responsibility and resource-based perspectives. Journal of business Ethics, 2006, 69.2: 111-132.

19) Porter, Michael E.; Kramer, Mark R. The link between competitive advantage and corporate social responsibility. Harvard business review, 2006, 84.12: 78-92.

20) Smith, N. Craig. Corporate social responsibility: whether or how?. California management review, 2003, 45.4: 52-76.

21) Evans, Daniel M.; Smith, Aaron CT. Internet sports marketing and competitive advantage for professional sports clubs: Bridging the gap between theory and practice. International Journal of Sports Marketing and Sponsorship, 2004.

22) Lii,, Yuan-Shuh; Lee, Monle. Doing right leads to doing well: When the type of CSR and reputation interact to affect consumer evaluations of the firm. Journal of business ethics, 2012, 105.1: 69-81.

23) Afrozeh, Mohammad Sadegh, Mozaffari, Seyed Amir Ahmad, Aghaei, Najaf, Saffari, Marjan. Developing a model of the consequences of the development of social responsibility of professional football clubs in Iran. Journal of Sports Management, 2017; 
8 (6): 977-997. doi: 10.22059 / jsm.2017.60799. (in Persian).

24) Atale, Nikhil; Helge, E. J. Proposed framework for government of India to effectively monitor mandatory CSR initiatives of public sector Enterprises in India. Journal of Human Values, 2014, 20.1: 75-83.

25) Mohammadi, Masoumeh, Bahr al-Ulum, Hassan, Hosseini Nia, Seyed Reza. Relationship between social responsibility and moral climate with perceived sports performance (Case study: Volleyball players of North Khorasan province). Human Resource Management in Sports, 2016; 3 (2): 165-174. doi: 10.22044 / shm.2016.834. (in Persian).

26) Rasoulzadeh, H., Hosseinipour, S. J., Yusof, N. A. M., Soltani, M., \& Hashemi, S. Effect of dimensions of corporate social responsibility on organization performance. International Journal of Innovative Ideas, 2013, 13.2: 37-47.

27) Palmer, Harmony J. Corporate social responsibility and financial performance: does it pay to be good?. 2012. CMC Senior Theses. 529.

28) Platonova, E., Asutay, M., Dixon, R., \& Mohammad, S. The impact of corporate social responsibility disclosure on financial performance: Evidence from the GCC Islamic banking sector. Journal of Business Ethics, 2018, 151.2: 451-471.

29) Carroll, Archie B.; Shabana, Kareem M. The business case for corporate social responsibility: A review of concepts, research and practice. International journal of management reviews, 2010, 12.1: 85-105.

30) Nyoro, Salome Njoki. Corporate social responsibility as a competitive strategy and its effect on performance of mobile telephone service industry: A case of Safaricom Kenya. International Academic Journal of Human Resource and Business Administration, 2015, 1.5: 1-12.

31) Bahr peymay pirbazari, Zahra; Shahnavazi, Abbas. Examining the effect of social responsibility, competitive advantage and customer satisfaction on financial performance (case study of the branches of the national bank of rasht)and management of Gilan Province's branches. PhD in the Islamic Azad University. 2015; (in Persian).

32) Amir Ghasemkhani, Somayeh; Kazemi, Mehdi; Mullah Hosseini, Ali. Corporate Social Responsibility and Its Role in Achieving Competitive Advantage, National Conference on New Achievements in Accounting and Management, Tehran, Applied Science Training Center, Unit 13, Tehran, Shabak Knowledge Management Institute. 2015; (2), 21-42. (in Persian).

33) Gallardo-Vázquez, Dolores; SANCHEZ-HERNANDEZ, M. Isabel. Measuring Corporate Social Responsibility for competitive success at a regional level. Journal of Cleaner Production, 2014, 72: 14-22.

34) Purat, Robabeh; Daimi, vahide. Investigating the Impact of Supply Chain Management on Improving the Performance of Sports Products through Competitive Advantage (Adidas Sports Products), 4th Iranian Scientific Research Conference on New Findings in Management, Entrepreneurship and Education, Tehran, Association for the Development and Promotion of Basic Sciences and Technologies - Scientific Association Civil and Architecture. 2016. (in Persian).

35) Powell, Thomas C. Competitive advantage: logical and philosophical considerations. Strategic management journal, 2001, 22.9: 875-888.

36) Brammer, Stephen; Pavelin, Stephen. Building a good reputation. European Management Journal, 2004, 22.6: 704-713.

37) Walker, Matthew, et al. Social responsibility and the Olympic Games: The mediating role 
of consumer attributions. Journal of business ethics, 2010, 95.4: 659-680.

38) Bakhshandeh, Hussein; Jalali Farahani, Majid; Sajjadi, Sayed Nasrallah. Investigating the effect of club social responsibility on the reputation of selected teams in the Iranian Football Premier League. Journal of Applied Research in Sports Management. 2016; 4 (16), 25-33. (in Persian).

39) Ghofrani, Mohsen. The relationship between social responsibility and the reputation of bodybuilding clubs in Sistan and Baluchestan province. Sports Management and Development. 2015; 4 (2): 71-81. (in Persian).

40) Sajadi, S. A. N., \& Javaran, S. H. The role of sr of club on fans' dependency club reputation (case study: on the team in the football premier league of iran). IIOAB journal. 2016; 7 , 583-587.

41) Polonsky, Michael Jay; Wood, Greg. Can the overcommercialization of cause-related marketing harm society?. Journal of macromarketing, 2001, 21.1: 8-22.

42) Graca, Casimiro Almeida M.; Arnaldo, Coelho. The role of corporate reputation on cooperants behavior and organizational performance. Journal of Management Development, 2016; 35(1), 17-37.

43) Martinez, A. D., Russell, Z. A., Maher, L. P., Brandon-Lai, S. A., \& Ferris, G. R. The sociopolitical implications of firm reputation: Firm financial reputation $\times$ social reputation interaction on firm financial performance. Journal of Leadership \& Organizational Studies, 2017, 24.1: 55-64.

44) Martínez, N. O., Carabel, T. C., \& del Castillo Feito, C. Legitimacy and Reputation of Organizations: Their Relationship with Management Systems and Financial Performance. In: Organizational Legitimacy. Springer, Cham, 2018. p. 141-157.

45) Zhu, Yan; Sun, Li-Yun; Leung, Alicia SM. Corporate social responsibility, firm reputation, and firm performance: The role of ethical leadership. Asia Pacific Journal of Management, 2014, 31.4: 925-947.

46) Surroca, J., Tribó, J. A., \& Waddock, S. Corporate responsibility and financial performance: The role of intangible resources. Strategic management journal, 2010, 31.5: 463-490.

47) Darabi, Samira, Zardoshtiyan, Shirin. The effect of social responsibility on organizational performance with emphasis on the strategic role of reputation on employees of sports and youth departments in western Iran. Journal of Organizational Behavior Management Studies in Sport, 2019; 5 (4): 109-123. doi: 10.30473 / fmss.2019.44571.1900. (in Persian).

48) AhadMotlaghi, Ehsan; Mostafavi, Masoud. An empirical study social responsibility of smes on export performance due to the mediating role of customer satisfaction (case study: Active companies in the polyethylene industry in tehran. QUID: Investigación, Ciencia y Tecnología, 2017, 1: 2291-2299.

49) Saeidi, S. P., Sofian, S., Saeidi, P., Saeidi, S. P., \& Saaeidi, S. A. How does corporate social responsibility contribute to firm financial performance? The mediating role of competitive advantage, reputation, and customer satisfaction. Journal of business research, 2015, 68.2: 341-350.

50) Sharifi, Seyed Rahim and Azami, Mohsen. The Impact of Social Responsibility on Company Performance with Mediating Role of Competitive Advantage, Organizational Reputation and Customer Satisfaction, Second National Conference on Modern Management Sciences and Sustainable Planning, Tehran. 2016. https: // civilica.com/doc/511406. (in Persian). 
51) Noorbakhsh, Haniyeh; Faizabadi, Yaser. Investigating the Impact of Social Responsibility on Financial Performance with the Mediating Role of Competitive Advantage, Reputation and Customer Satisfaction Case Study: Bank Mellat Branches, Sari, 5th International Conference on Accounting and Management with Modern Research Approach, Tehran, Arghavan Iranian Communication Company. 2016. (in Persian).

52) Cantele, S., \& Zardini, A. Is sustainability a competitive advantage for small businesses? An empirical analysis of possible mediators in the sustainability-financial performance relationship. Journal of Cleaner Production, 2018, 182: 166-176.

53) Galbreth, Jeremy. How does corporate social responsibility benefit firms? Evidence from Australia. European Business Review, 2010; 411-431.

54) Hosseini, Akram. Investigating the effect of managers' commercialization skills on the performance of private sports clubs in Qazvin, M.Sc. Thesis, Islamic Azad University, Research Sciences Branch. 2016. (in Persian).

55) Glenn, S. D. Filling the leadership void: The impact of peer and coach leaders on team dynamics and performance (Doctoral dissertation, University of Idaho). 2003.

56) Cooper, D. J., \& Sutter, M. Role selection and team performance. IZA Discussion Pape. 2011; r No. 58-92.

57) Ressler, M. J. An Examination Of Belief And Attitude Based Reputation And Its Impact On Behavioral Consequences. Nova Southeastern University. Doctoral Dissertation, Doctor Of Business Administration: Evolution And Interpretation. Perspectives On Corporate Citizenship.2010; 39-52.

58) Hosseini, Soheila. Investigating the Relationship between Marketing Performance and Competitive Advantage (Case Study: Commercial Banks of Kurdistan Province). Master Thesis. Islamic Azad University, Sanandaj Branch.2011. (in Persian).

59) Hair Jr JF, Hult GT, Ringle C, Sarstedt M. A primer on partial least squares structural equation modeling (PLS-SEM). Sage Publications. 1st Edition; 2014.

60) Henseler, J., Hubona, G., \& Ray, P. A. Using PLS path modeling in new technology research: updated guidelines. Industrial management \& data systems, 2016; 116(1), 220.

61) Richter, N. F., Sinkovics, R. R., Ringle, C. M., \& Schlaegel, C. A critical look at the use of SEM in international business research. International Marketing Review, 2016; 33(3), 376404.

62) Henseler, J., Ringle, C. M., \& Sinkovics, R. R. The use of partial least squares path modeling in international marketing. In New challenges to international marketing (pp. 277319). Emerald Group Publishing Limited. 2009.

63) Hair Jr JF, Hult GT, Ringle C, Sarstedt M. A primer on partial least squares structural equation modeling (PLS-SEM). Sage Publications. Second Edition. 2016.

64) Aupperle, K. E., Carroll, A. B., \& Hatfield, J. D. An empirical examination of the relationship between corporate social responsibility and profitability. Academy of management Journal.1985; 28(2), 446-463.

65) Nelling, E., \& Webb, E. Corporate social responsibility and financial performance: the "virtuous circle" revisited. Review of Quantitative Finance and Accounting. 2009; 32(2), 197-209.

66) Akbari M, Nikokar H, Esmailzadeh M. Studying Role and Effects of Transcendental Leadership on Organizational Performance Considering Competitive Advantage. ORMR. 2016; 6 (3) :1-17. (in Persian). 